Supplemental Information for

\title{
Temporal multiplexed in vivo upconversion imaging
}

Hui Li, Meiling Tan, Xin Wang, Feng Li, Yuqi Zhang, LiLi Zhao, Chunhui Yang, and Guanying Chen*

MIIT Key Laboratory of Critical Materials Technology for New Energy Conversion and Storage, School of Chemistry and Chemical Engineering \& Key Laboratory of Micro-systems and Micro-structures, Ministry of Education, Harbin Institute of Technology, Harbin 150001, People's Republic of China

${ }^{*}$ Correspondence: chenguanying@hit.edu.cn 


\section{TABLE OF CONTENTS}

\section{Experimental Procedures}

Materials. Detailed procedures of preparing shell precursors and designated nanoparticles. Surface Modification. Nearinfrared upconversion imaging. Algorithm for temporal upconversion imaging. Cytotoxicity. Animal experiments. Preparing anti-counterfeiting patterns.

\section{Supporting Figures and Tables}

Figure S1. Lateral upconversion imaging resolution through biological tissues.

Figure S2. Upconversion luminescence intensity and lifetime imaging through biological tissues of varying thicknesses.

Figure S3. The comparation of SNR of the intensity images employing DSNPs and UCNPs under TG mode.

Figure S4. Mouse temperature elevation under pulsed versus continuous-wave laser irradiation at $980 \mathrm{~nm}$.

Figure S5. TEM images pertaining to $\mathrm{NaYF}_{4} @ \mathrm{NaYbF}_{4} @ \mathrm{NaYF}_{4}: \mathrm{Yb}^{3+} / \mathrm{Tm}^{3+} @ \mathrm{NaYF}_{4}$ nanoparticles with varying thicknesses of the energy migration shell $\left(\mathrm{NaYbF}_{4}\right)$.

Figure S6. Size histograms pertaining to $\mathrm{NaYF}_{4} @ \mathrm{NaYbF}_{4} @ \mathrm{NaYF}_{4}: \mathrm{Yb}^{3+} / \mathrm{Tm}^{3+} @ \mathrm{NaYF}_{4}$ nanoparticles with varying thicknesses of the energy migration shell $\left(\mathrm{NaYbF}_{4}\right)$.

Figure S7.TEM images pertaining to $\mathrm{NaYF}_{4} @ \mathrm{NaYbF}_{4} @ \mathrm{NaYF}_{4}: \mathrm{Yb}^{3+} / \mathrm{Tm}^{3+} @ \mathrm{NaYF}_{4}$ nanoparticles with varying $\mathrm{Yb}^{3+}$ dopant concentrations in the upconverting shell $\left(\mathrm{NaYF}_{4}: \mathrm{Yb}^{3+} / \mathrm{Tm}^{3+}\right)$.

Figure S8. Size histograms pertaining to $\mathrm{NaYF}_{4} @ \mathrm{NaYbF}_{4} @ \mathrm{NaYF}_{4}: \mathrm{Yb}^{3+} / \mathrm{Tm}^{3+} @ \mathrm{NaYF}_{4}$ nanoparticles with varying $\mathrm{Yb}^{3+}$ dopant concentrations in the upconverting shell $\left(\mathrm{NaYF}_{4}: \mathrm{Yb}^{3+} / \mathrm{Tm}^{3+}\right)$.

Figure S9.XRD patterns pertaining to $\mathrm{NaYF}_{4} @ \mathrm{NaYbF}_{4} @ \mathrm{NaYF}_{4}: \mathrm{Yb}^{3+} / \mathrm{Tm}^{3+} @ \mathrm{NaYF}_{4}$ nanoparticles in Figure 2b.

Figure S10. The downshifting luminescence decay profiles of 980 nm emitted by $\mathrm{NaYF}_{4} @ \mathrm{NaYbF}_{4} @ \mathrm{NaYF}_{4}: \mathrm{Yb}^{3+} / \mathrm{Tm}^{3+}$ nanoparticles with varying thicknesses of $\mathrm{NaYbF}_{4}$ layer.

Figure S1 1. Upconversion luminescence lifetime and intensity of $\mathrm{NaYF}_{4} @ \mathrm{NaYbF}_{4} @ \mathrm{NaYF}_{4}: \mathrm{Yb}^{3+} / \mathrm{Tm}^{3+}$ nanoparticles with varying $\mathrm{Yb}^{3+}$ dopant concentration in the upconverting shell $\left(\mathrm{NaYF}_{4}: \mathrm{Yb}^{3+} / \mathrm{Tm}^{3+}\right)$.

Figure S12. Back energy transfer process from $\mathrm{Tm}^{3+}$ to $\mathrm{Yb}^{3+}$ ions.

Figure S13. Upconversion luminescence lifetime and intensity for $\mathrm{NaYF}_{4} @ \mathrm{NaYbF}_{4} @ \mathrm{NaYF}_{4}: \mathrm{Yb}^{3+} / \mathrm{Tm}^{3+}$ nanoparticles with varying $\mathrm{Yb}^{3+}$ dopant concentrations in the upconverting shell $\left(\mathrm{NaYF}_{4}: \mathrm{Yb}^{3+} / \mathrm{Tm}^{3+}\right)$.

Figure S14. Absolute quantum yields of tetradomain core/multishell $\mathrm{NaYF}_{4} @ \mathrm{NaYbF}_{4} @ \mathrm{NaYF}_{4}: \mathrm{Yb}^{3+} / \mathrm{Tm}^{3+} @ \mathrm{NaYF}_{4}$ upconversion nanoparticles.

Figure S15. Fourier transform infrared (FTIR) spectra of $\mathrm{NaYF}_{4} @ \mathrm{NaYbF}_{4} @ \mathrm{NaYF}_{4}: \mathrm{Yb}^{3+} / \mathrm{Tm}^{3+} @ \mathrm{NaYF}_{4}$ upconversion nanoparticles before and after PAA surface modifications.

Figure S16. Colloidal stabilities of $\mathrm{PAA}$-coated $\mathrm{NaYF}_{4} @ \mathrm{NaYbF}_{4} @ \mathrm{NaYF}_{4}: \mathrm{Yb}^{3+} / \mathrm{Tm}^{3+} @ \mathrm{NaYF}_{4}$ upconversion nanoparticles in PBS.

Figure S17. The stability of core/multishell UCNPs with the lifetime of $\tau_{5}$ in various aqueous media.

Figure S18. Cytotoxic studies of PAA-coated $\mathrm{NaYF}_{4} @ \mathrm{NaYbF}_{4} @ \mathrm{NaYF}_{4}: \mathrm{Yb}^{3+} / \mathrm{Tm}^{3+} @ \mathrm{NaYF}_{4}$ upconversion nanoparticles. 
Figure S19. The in vivo multiplexed lifetime imaging of two UCNPs with close lifetime $\left(\tau_{2}\right.$ and $\left.\tau_{3}\right)$.

Table S1. Compiled upconversion luminescence lifetimes (at $808 \mathrm{~nm}$ ) and structure compostion pertaining to $\mathrm{NaYF}_{4} @ \mathrm{NaYbF}_{4} @ \mathrm{NaYF}_{4}: \mathrm{Yb}^{3+} / \mathrm{Tm}^{3+} @ \mathrm{NaYF}_{4}$ nanoparticles.

Table S2. Compiled upconversion luminescence lifetimes (at $808 \mathrm{~nm}$ ) and structure compostion pertaining to $\mathrm{NaYF}_{4} @ \mathrm{NaYbF}_{4} @ \mathrm{NaYF}_{4}: \mathrm{Yb}^{3+} / \mathrm{Tm}^{3+}$ nanoparticles. 


\section{Experimental Procedures}

\section{Materials}

Yttrium (III) chloride hexahydrate $\left(\mathrm{YCl}_{3} \cdot 6 \mathrm{H}_{2} \mathrm{O}, 99.99 \%\right)$, rare earth oxides $\left(\mathrm{Y}_{2} \mathrm{O}_{3}, \mathrm{Yb}_{2} \mathrm{O}_{3}, \mathrm{Tm}_{2} \mathrm{O}_{3}, 99.99 \%\right)$, sodium trifluoroacetate $\left(\mathrm{CF}_{3} \mathrm{COONa}, 98 \%\right)$, trifluoroacetic acid (TFA), sodium oleate (Na-OA, >97\%), N,N-dimethylformamide (DMF), N-hydroxysulfosuccinimide sodium salt $\left(\mathrm{NOBF}_{4}, 97 \%\right)$, polyacrylic acid (PAA, mw=15000) were all purchased from Aladdin. Oleic acid (OA, tech grade, 90\%), 1-octadecene (ODE, tech grade, 90\%) and oleylamine (OM, tech grade, 70\%) were purchased from Sigma Aldrich. All materials were used as received without further purification.

\section{Preparation of $\operatorname{Re}\left(\mathrm{CF}_{3} \mathrm{COO}\right)_{3}(\operatorname{Re}=\mathrm{Y}, \mathrm{Yb}, \mathrm{Tm})$ precursors}

$\operatorname{Re}\left(\mathrm{CF}_{3} \mathrm{COO}\right)_{3}(\mathrm{Re}=\mathrm{Y}, \mathrm{Yb}$ or $\mathrm{Tm})$ precursors were prepared using the following procedure adapted from our previous publication ${ }^{1}$. Firstly, $2 \mathrm{mmol}$ corresponding rare earth oxides were dissolved in $20 \mathrm{ml}$ TFA solution of $50 \%$ (v/v) under heating at $90^{\circ} \mathrm{Cin}$ a three-neck flask, yielding a transparent solution. Subsequently, the solution was evaporated to dryness under argon gas protection, and the final $\operatorname{Re}\left(\mathrm{CF}_{3} \mathrm{COO}\right)_{3}(\mathrm{Re}=\mathrm{Y}, \mathrm{Yb}$ or $\mathrm{Tm})$ precursors of white powder were collected for further uses.

\section{Preparation of $\mathrm{Yb}(\mathrm{Y})-\mathrm{OA}$ precursors for the energy migration (outmost) shell}

The $\mathrm{Yb}(\mathrm{Y})$-OA precursors were prepared following a literature method with adaptations ${ }^{2}$. Typically, $4 \mathrm{mmol}$ $\mathrm{Yb}\left(\mathrm{CF}_{3} \mathrm{COO}\right)_{3}$ was added into a $100 \mathrm{ml}$ 3-neck flask containing $4 \mathrm{ml} \mathrm{OA}, 1 \mathrm{ml} \mathrm{OM}$ and $6 \mathrm{ml}$ ODE. Then, the mixture solution was heated to $120^{\circ} \mathrm{C}$ and maintained at this temperature for $45 \mathrm{~min}$ under argon gas protection, yielding a clear and slightly yellow solution. After naturally cooling down to room temperature, the viscous precursor liquid was stored in a glass vial for further uses.

\section{Preparation of (99-x)\%Y, $\mathrm{x} \% \mathrm{Yb}, 1 \% \mathrm{Tm}-\mathrm{OA}$ precursors for the upconverting shell}

The procedure of preparing $\mathrm{Y}, \mathrm{x} \% \mathrm{Yb}, 1 \% \mathrm{Tm}-\mathrm{OA}$ precursors is almost identical to that for the preparation of $\mathrm{Yb}(\mathrm{Y})-\mathrm{OA}$ precursor. The difference lies in the use of a mixture of $4 \mathrm{mmol} \operatorname{Re}\left(\mathrm{CF}_{3} \mathrm{COO}\right)_{3}$ with a corresponding ratio of $(99-\mathrm{x}) / \mathrm{x} / 1$ to yield the $\mathrm{Y}, \mathrm{x} \% \mathrm{Yb}, 1 \% \mathrm{Tm}-\mathrm{OA}$ precursors.

\section{Preparation of $\mathrm{Na}-\mathrm{OA}$ shell precursors for all shells}

$4 \mathrm{mmol} \mathrm{CF}_{3} \mathrm{COONa}$ was added into a $20 \mathrm{ml}$ glass vial containing $4.5 \mathrm{ml} \mathrm{OA}$ and $4.5 \mathrm{ml}$ ODE. The mixture was ultrasounded until a complete dissolution of the solid $\mathrm{CF}_{3} \mathrm{COONa}$, yielding a clear solution. Then, the vial was stored at room temperature for further uses.

The final precursors for shelling growth were obtained by mixing aliquots of $\mathrm{Re}-\mathrm{OA}(\mathrm{Re}=\mathrm{Y}, \mathrm{Yb}$ or $\mathrm{Y} / \mathrm{Yb} / \mathrm{Tm}$ ) and $\mathrm{Na}$ OA precursors ( $\mathrm{Re}: \mathrm{Na}=1: 1)$ into a vial under ultrasound for one hour, yielding molar concentrations of both rare-earth oleate and $\mathrm{Na}-\mathrm{OA}$ to be $0.2 \mathrm{M}$. These precursors were then utilized for growth of the outmost shell layer, the energy migration shell layer, and the upconverting shell layer, respectively. 


\section{Synthesis of the inert core $\beta-\mathrm{NaYF}_{4}$ nanoparticles}

The inert $\beta-\mathrm{NaYF}_{4}$ core nanoparticles with a small size of $5.9 \mathrm{~nm}$ were prepared following our previously reported method with adaptations ${ }^{3}$.

First, Y-OA precursors were prepared using the following procedure. $1 \mathrm{mmol} \mathrm{YCl}_{3} \cdot 6 \mathrm{H}_{2} \mathrm{O}$ and $3 \mathrm{mmol}$ sodium oleate were dissolved in a mixed solution containing $3 \mathrm{ml}$ deionized water, $3.5 \mathrm{ml}$ absolute ethyl alcohol and $7 \mathrm{ml}$ hexane. The resulting mixture was then heated to $60^{\circ} \mathrm{C}$ and kept at this temperature for $12 \mathrm{~h}$. The organic phase solvent containing Y-OA was collected by washing the final complex three times with deionized water in a separatory funnel.

Second, the obtained Y-OA precursor were mixed with $8 \mathrm{mmol}$ sodium oleate, $5.2 \mathrm{ml} \mathrm{OA}, 5.1 \mathrm{ml} \mathrm{OM}$ and $9 \mathrm{ml}$ ODE. The solution was then heated up to $100^{\circ} \mathrm{C}$ under argon gas protection with vigorous magnetic stirring for 60 min to remove water and hexane. Subsequently, $8 \mathrm{mmol}$ solid ammonium fluoride was added to the solution and kept at $100^{\circ} \mathrm{C}$ for another $30 \mathrm{~min}$. Last, the reaction mixture was heated to $300^{\circ} \mathrm{C}$ at a rate of $10 \mathrm{~K} \cdot \mathrm{min}^{-1}$, kept at this temperature for $30 \mathrm{~min}$, and then allowed to cool down to room temperature naturally. The resulting $\beta-\mathrm{NaYF}_{4} \mathrm{NPs}$ were precipitated by addition of $20 \mathrm{ml}$ ethanol, collected via centrifugation at $6000 \mathrm{rpm}$ for $5 \mathrm{mins}$, subsequently washed twice with a hexane/ethanol mixture $(\mathrm{v} / \mathrm{v}=1 / 1)$, and finally dispersed in $10 \mathrm{ml}$ hexane for further uses.

\section{Synthesis of the core/shell $\mathrm{NaYF}_{4} @ \mathrm{NaYbF}_{4}$ nanoparticles with varying $\mathrm{NaYbF}_{4}$ thicknesses}

The $\mathrm{NaYF}_{4} @ \mathrm{NaYbF}_{4}$ nanoparticles with varying shell thicknesses $(1.5,3.0,5.0$, and $8 \mathrm{~nm})$ was prepared following a literature hot-injection method with adaptations ${ }^{2}$. Typically, $2.5 \mathrm{ml}(0.25 \mathrm{mmol})$ hexane dispersed $\beta-\mathrm{NaYF}_{4}$ inert core NPs was first mixed with $6 \mathrm{ml} \mathrm{OA}$ and $15 \mathrm{ml} \mathrm{ODE}$ in a 3-neck flask $(250 \mathrm{ml})$, the mixture was heated to $120^{\circ} \mathrm{C}$ for $30 \mathrm{~min}$, and then to $300{ }^{\circ} \mathrm{C}$ at a rate of $10 \mathrm{~K} \cdot \mathrm{min}^{-1}$ under argon gas protection. Subsequently, an aliquot of energy migration shell precursors ( $1 \mathrm{ml}$ ) that contains $0.2 \mathrm{mmol} \mathrm{Yb}-\mathrm{OA}$ and $0.2 \mathrm{mmol} \mathrm{Na}-\mathrm{OA}$ was consecutively injected into the solution per an interval of $10 \mathrm{~min}$. A controlled injection volume of shell precursors $(3,5,10$, and $20 \mathrm{ml})$ resulted in a precisely controlled $\mathrm{NaYbF}_{4}$ shell thickness $(1.5,3.0,5.0$, and $8.0 \mathrm{~nm})$. After completion of shell growth, the reaction was allowed to cool down to room temperature by removing the heating mantle. The resultant $\mathrm{NaYF}_{4} @ \mathrm{NaYbF}_{4}$ nanoparticles was collected using the identical procedure as that for the parent inert $\beta-\mathrm{NaYF}_{4}$ core nanoparticles, and then dispersed in $10 \mathrm{ml}$ hexane for further uses.

\section{Synthesis of $\mathrm{NaYF}_{4} @ \mathrm{NaYbF}_{4} @ \mathrm{NaYbF}_{4}: 1 \% \mathrm{Tm}^{3+}$ nanoparticles with varying $\mathrm{NaYbF}_{4}$ thicknesses}

The procedure of synthesizing $\mathrm{NaYF}_{4} @ \mathrm{NaYbF}_{4} @ \mathrm{NaYbF}_{4}: 1 \% \mathrm{Tm}^{3+}$ nanoparticles, with varying $\mathrm{NaYbF}_{4}$ shell thicknesses $(1.5,3.0,5.0$, and $8.0 \mathrm{~nm})$, is identical to that for the preparation of $\mathrm{NaYF}_{4} @ \mathrm{NaYbF}_{4}$ nanoparticles. The difference lies in the use of $\mathrm{NaYF}_{4} @ \mathrm{NaYbF}_{4}$ to replace the inert core $\mathrm{NaYF}_{4}$, and the use of $\mathrm{NaYbF}_{4}: 1 \% \mathrm{Tm}^{3+}$ shelling precursors to substitute the $\mathrm{NaYbF}_{4}$ shelling precursors. A fixed total volume of $6 \mathrm{ml}$ precursors is injected for the growth of $\mathrm{NaYbF}_{4}: 1 \% \mathrm{Tm}^{3+}$ shell $(3.5 \mathrm{~nm})$.

\section{Synthesis of $\mathrm{NaYF}_{4} @ \mathrm{NaYbF}_{4}(8.0 \mathrm{~nm}) @ \mathrm{NaYF}_{4}: \mathrm{x} \% \mathrm{Yb}^{3+}, 1 \% \mathrm{Tm}^{3+}(3.5 \mathrm{~nm})$ nanoparticles $(\mathrm{x}=10,20,40,50,70$, and 99).}

The procedure for synthesizing $\mathrm{NaYF}_{4} @ \mathrm{NaYbF}_{4}(8.0 \mathrm{~nm}) @ \mathrm{NaYF}_{4}: \mathrm{x}^{2} \mathrm{Yb}^{3+}, 1 \% \mathrm{Tm}^{3+}(3.5 \mathrm{~nm})$ nanoparticles $(\mathrm{x}=10$, 20, 40, 50, 70, and 99) nanoparticles is identical to that for the preparation of $\mathrm{NaYF}_{4} @ \mathrm{NaYbF}_{4} @ \mathrm{NaYbF}_{4}: 1 \% \mathrm{Tm}^{3+}$ nanoparticles described above. The only difference lies in the use of $(99-\mathrm{x}) \% \mathrm{Y}, \mathrm{x} \% \mathrm{Yb}, 1 \% \mathrm{Tm}-\mathrm{OA}(\mathrm{x}=10,20,40,50,70$, and 99 ) shelling precursors to substitute the $99 \% \mathrm{Yb}, 1 \% \mathrm{Tm}-\mathrm{OA}$ precursors. 


\section{Synthesis of $\mathrm{NaYF}_{4} @ \mathrm{NaYbF}_{4} @ \mathrm{NaYF}_{4}: \mathrm{Yb}^{3+} / \mathrm{Tm}^{3+} @ \mathrm{NaYF}_{4}$ core/multishell nanoparticles}

The procedure of synthesizing $\mathrm{NaYF}_{4} @ \mathrm{NaYbF}_{4} @ \mathrm{NaYF}_{4}: \mathrm{Yb}^{3+} / \mathrm{Tm}^{3+} @ \mathrm{NaYF}_{4}$ nanoparticles is almost identical to the one for preparing $\mathrm{NaYF}_{4} @ \mathrm{NaYbF}_{4} @ \mathrm{NaYbF}_{4}: 1 \% \mathrm{Tm}^{3+} \mathrm{NPs}$. The difference lies in the use of the $\mathrm{NaYF}_{4} @ \mathrm{NaYbF}_{4} @ \mathrm{NaYF}_{4}$ : $\mathrm{Yb}^{3+} / \mathrm{Tm}^{3+}$ to substitute $\mathrm{NaYF}_{4} @ \mathrm{NaYbF}_{4}$ as a core for seed-mediated growth. And, a total amount of $7 \mathrm{ml}$ shelling precursor (containing $1.4 \mathrm{mmol} \mathrm{Y}-\mathrm{OA}$ and $1.4 \mathrm{mmol} \mathrm{Na}-\mathrm{OA}$ ) was aliquoted for seven separate injections per an injection interval of $13 \mathrm{~min}$.

\section{Surface modification}

A ligand exchange procedure was implemented to substitute the pristine hydrophobic oleic acid ligand of the as-prepared core/multishell nanoparticles with hydrophilic PAA ligand, rendering these nanoparticles dispersible in phosphate buffer saline (PBS) ${ }^{4}$. Typically, $2 \mathrm{ml}$ as-prepared $\mathrm{NaYF}_{4} @ \mathrm{NaYbF}_{4} @ \mathrm{NaYF}_{4}: \mathrm{Yb}^{3+} / \mathrm{Tm}^{3+} @ \mathrm{NaYF}_{4}$ nanoparticles dispersed in hexane (ca. $40 \mathrm{mg} / \mathrm{ml}$ ) was first mixed with a $5 \mathrm{ml} \mathrm{N}$, N-dimethylformamide (DMF) solution of $\mathrm{NOBF}_{4}(0.01 \mathrm{M})$ at room temperature. After gently shake for about $30 \mathrm{~min}$, these nanoparticles capped by ionic $\mathrm{NOBF}_{4}$ ligand were precipitated by addition of $20 \mathrm{ml}$ mixture of toluene and hexane $(1: 1 \mathrm{v} / \mathrm{v})$, and then collected by centrifugation at $8000 \mathrm{rpm}$ for $10 \mathrm{~min}$. Subsequently, the collected precipitation ( $\mathrm{NOBF}_{4}$-capped nanoparicles) was re-dispersed in $5 \mathrm{ml}$ DMF that contains 300 mg PAA. Next, the resultant solution was heated to $80^{\circ} \mathrm{C}$ maintained at this temperature for $30 \mathrm{~min}$, and then allowed to cool down to the room temperature. The PAA-coated core/multishell nanoparticles were precipitated by addition of $10 \mathrm{~mL}$ acetone, collected via centrifugation at $6000 \mathrm{rpm}$ for $5 \mathrm{~min}$, washed with ethanol for 3 times, and finally re-dispersed in 4 $\mathrm{mL}$ normal PBS saline. The transparent solution was stored in refrigerator $\left(5^{\circ} \mathrm{C}\right)$ for later uses.

\section{Characterizations}

The size and morphology of the resultant nanoparticles were characterized by transmission electron microscopy (TEM) using a JEOL JEM-2010 microscope (JEOL Ltd., Tokyo, Japan) at an acceleration voltage of $200 \mathrm{kV}$. The size histograms were derived from TEM images by analyzing the diameter of a minimum of 100 particles using Image J software. The crystal phase of the resultant nanoparticles was analyzed by power x-ray diffraction (XRD), which was recorded on a Siemens D500 diffractometer using $\mathrm{Cu} K \alpha$ radiation $(\lambda=0.15418 \mathrm{~nm})$ at a scanning speed of $5 \%$ minute. The upconversion luminescence spectra and absolute quantum yield (QY) of the corresponding nanoparticles were collected by a steady/transient fluorescence spectrometer (FLS-1000, Edinburgh) using a $980 \mathrm{~nm}$ continuous-wave (CW) laser as an external excitation. The luminescence lifetimes of $\mathrm{Tm}^{3+}$ ions at $808 \mathrm{~nm}$ were also recorded on the FLS-1000 spectrometer using the same 980 nm laser but operating in a pulsed mode. Fourier transform infrared (FTIR) spectra ofOA- and PAA-coated core/multishell nanoparticles were measured using a Perkin-Elmer 580B infrared spectrophotometer. Dynamic light scattering (DLS) of PAA-coated core/multishell nanoparticles were performed on a Zetasizer Nano ZS (Malvern Instruments Lte., UK). Thermal images of a Kunming mouse under continuous-wave (CW) and pulsed mode exciation at $980 \mathrm{~nm}$ were recorded by an infrared thermal camera (Fotric $280 \mathrm{~s}$, Shanghai, China).

\section{Cytotoxicity}

The cytotoxicity of PAA-coated $\mathrm{NaYF}_{4} @ \mathrm{NaYbF}_{4} @ \mathrm{NaYF}_{4}: \mathrm{Yb}^{3+} / \mathrm{Tm}^{3+} @ \mathrm{NaYF}_{4}$ core/multishell nanoparticles was investigated using MTT [3-(4, 5-dimethylthiazol-2-yl)-2, 5-diphenyltetrazolium bromide] cell assay. Firstly, HeLa cells were seeded in a 96-well flat-bottomed microplate with about 10000 cells in each well. Then, after incubating with $100 \mu \mathrm{L}$ growth medium at $37^{\circ} \mathrm{C}$ and $5 \% \mathrm{CO}_{2}$ for $24 \mathrm{~h}$, the cells were allowed to attach to the bottom of wells. Subsequently, the PAA-coated core/multishell nanoparticles were added to the wells at different concentrations of $0,31.25,62.5,125,250$, 
500 and $1000 \mu \mathrm{g} / \mathrm{ml}$, and allowed to incubate with HeLa cells for $24 \mathrm{~h}$ and $48 \mathrm{~h}$ before adding MTT solution. The number of viable cells was calculated by measuring the activity of $\mathrm{NADH}$-dependent cellular oxidoreductase in cells.

\section{Steady-state and temporal upconversion luminescence imaging}

Steady-state upconversion luminescence imaging was performed in a home-built imaging system equipped with a silicon camera (Model: Retiga LUMO CCD camera, QImaging Corporation, Canada) and a fiber-coupled 980 lasers that produce a homogenous laser irradiance of $0.12 \mathrm{~W} / \mathrm{cm}^{2}$ over a $25 \times 25 \mathrm{~cm}^{2}$ area for imaging. A band-pass filter of $808 \mathrm{~nm}$ and a band elimination filter of $980 \mathrm{~nm}$ were placed in front of the imaging camera. The laser is running in a continuous-wave mode for steady-state upconversion luminescence imaging.

Temporal upconversion luminescence imaging was performed using the same imaging system, but the excitation laser at $980 \mathrm{~nm}$ was operated in a square-wave pulsed mode ( $40 \%$ duty-cycle, $1 \mathrm{~Hz}$ ). The imaging camera was synchronized with the excitation laser, but triggered at a precisely defined delay time. After triggering, the camera kept integrating till the arrival of next laser pulse. A series of time-delayed images was collected for algorithm computation.

\section{Algorithm for temporal upconversion luminescence imaging}

A series of time-delayed upconversion luminescence images with a wide range of time delays can be converted into temporal lifetime-encoded imaging using the following algorithm. For each imaging pixel, the upconversion luminescence intensity can be fitted with multi-exponential functions (All calculations were carried out in MATLAB):

$$
\text { I }(\mathrm{t})=A_{1} \exp \left(-t / \tau_{1}\right)+A_{2} \exp \left(-t / \tau_{2}\right)+\cdots+A_{n} \exp \left(-t / \tau_{n}\right)+C
$$

where $\mathrm{I}(\mathrm{t})$ represents the luminescence intensity at time $\mathrm{t}, \mathrm{A}_{1}, \mathrm{~A}_{2} \ldots, \mathrm{A}_{\mathrm{n}}$ are the amplitudes of the upconversion luminescence components with a corresponding lifetimes of $\tau_{1}, \tau_{2}, \ldots, \tau_{\mathrm{n}}$, and $\mathrm{C}$ stands for the imaging background level.

For a single lifetime used, the equation can be simplified as:

$$
\text { I }(\mathrm{t})=I_{0} \exp (-t / \tau)+C
$$

where $\mathrm{I}(\mathrm{t})$ represents the luminescence intensity at time $t, \mathrm{I}_{0}$ stands for the luminescence intensity at $t=0, t$ is the delay time, $\mathrm{C}$ is the background level and $\tau$ is the lifetime of ${ }^{3} \mathrm{H}_{4}$ energy level of $\mathrm{Tm}^{3+}$.

\section{Animal experiments}

Two Kunming female mouse (about $20 \mathrm{~g}$ ) were barbered after anaesthetizing by intraperitoneal injection of $50 \mu \mathrm{l} 5 \%$ chloral hydrate solution. Then, $20 \mu \mathrm{L}$ PAA-coated core/multishell nanoparticles dispersed in PBS $\left(30 \mathrm{mg} \mathrm{mL}^{-1}\right)$ with lifetimes of $\tau_{2}$ and $\tau_{9}$ were subcutaneously administrated to the left and right abdomen (with a gauged depth of $2 \mathrm{~mm}$ ). One mouse was then transferred into imaging chamber for temporal upconversion luminescence lifetime imaging. In addition, the other one was injected through tail vein with $100 \mu \mathrm{L}$ PAA-coated core/multishell nanoparticles dispersed in PBS (30 $\mathrm{mg} \mathrm{mL}^{-1}$ ) with a lifetime of $\tau_{5}$. After $20 \mathrm{~min}$ blood circulation, this mouse was also transferred to imaging chamber for temporal multicolor upconversion luminescence imaging.

\section{Preparing anti-counterfeiting patterns}

The tail, eyes, head, legs of an elephant pattern were made with frequently lab-used filter paper, which were loaded through absorption with transparent hexane-dispersed core/multishell nanoparticles $\left(20 \mathrm{mg} \mathrm{ml}^{-1}\right)$ with lifetimes of $\tau_{1}, \tau_{3}, \tau_{7}$, 
and $\tau_{8}$, respectively. After natural volatilization of hexane in air, the elephant filter paper containing core/multishell upconversion nanoparticles was covered by another filter paper that was printed with a butterfly pattern using black commercial ink. The secured two-layer pattern was then utilized for the anti-counterfeiting experiment. 
2. Supporting Figures

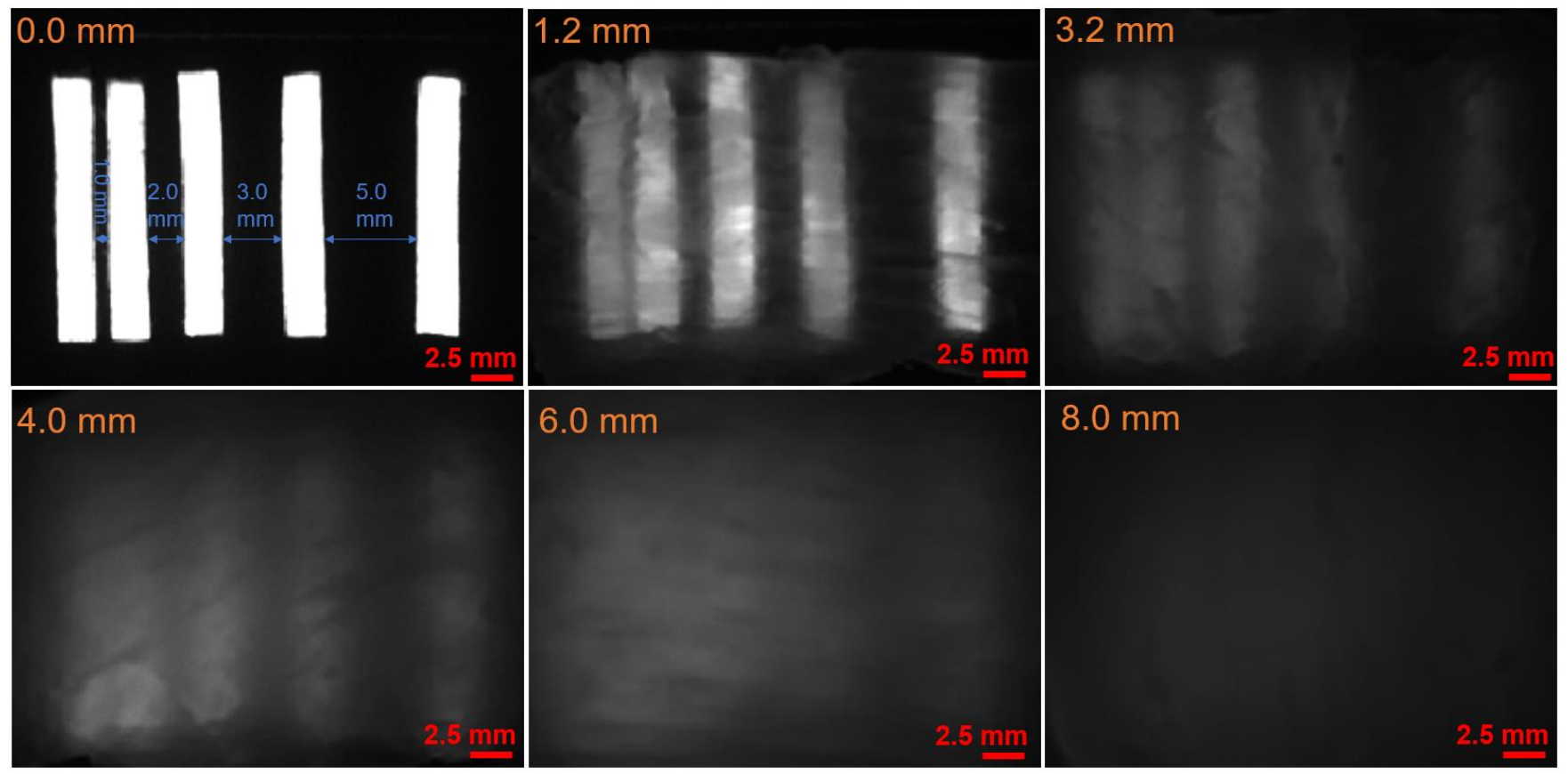

Figure S1. Lateral upconversion imaging resolution through biological tissues. Upconversion luminescence imaging of five strips, made with filter paper, through varying thicknesses pork tissue $(0,1.2,3.2,4.0,6.0 \mathrm{~mm}$, and $8.0 \mathrm{~mm})$ was performed. These strips were preloaded with PAA-coated $\mathrm{NaYF}_{4} @ \mathrm{NaYbF}_{4} @ \mathrm{NaYF}_{4}: \mathrm{Yb}^{3+} / \mathrm{Tm}^{3+} @ \mathrm{NaYF}_{4}$ core/multishell nanoparticles (with a lifetime of $\tau_{5}$ ), and placed with defined distances $(1,2,3$, and $5 \mathrm{~mm}$ ). Excitation at $\sim 980 \mathrm{~nm}$ with a power density of $0.12 \mathrm{~W} / \mathrm{cm}^{2}$, the exposure time is $50 \mathrm{~ms}$. 


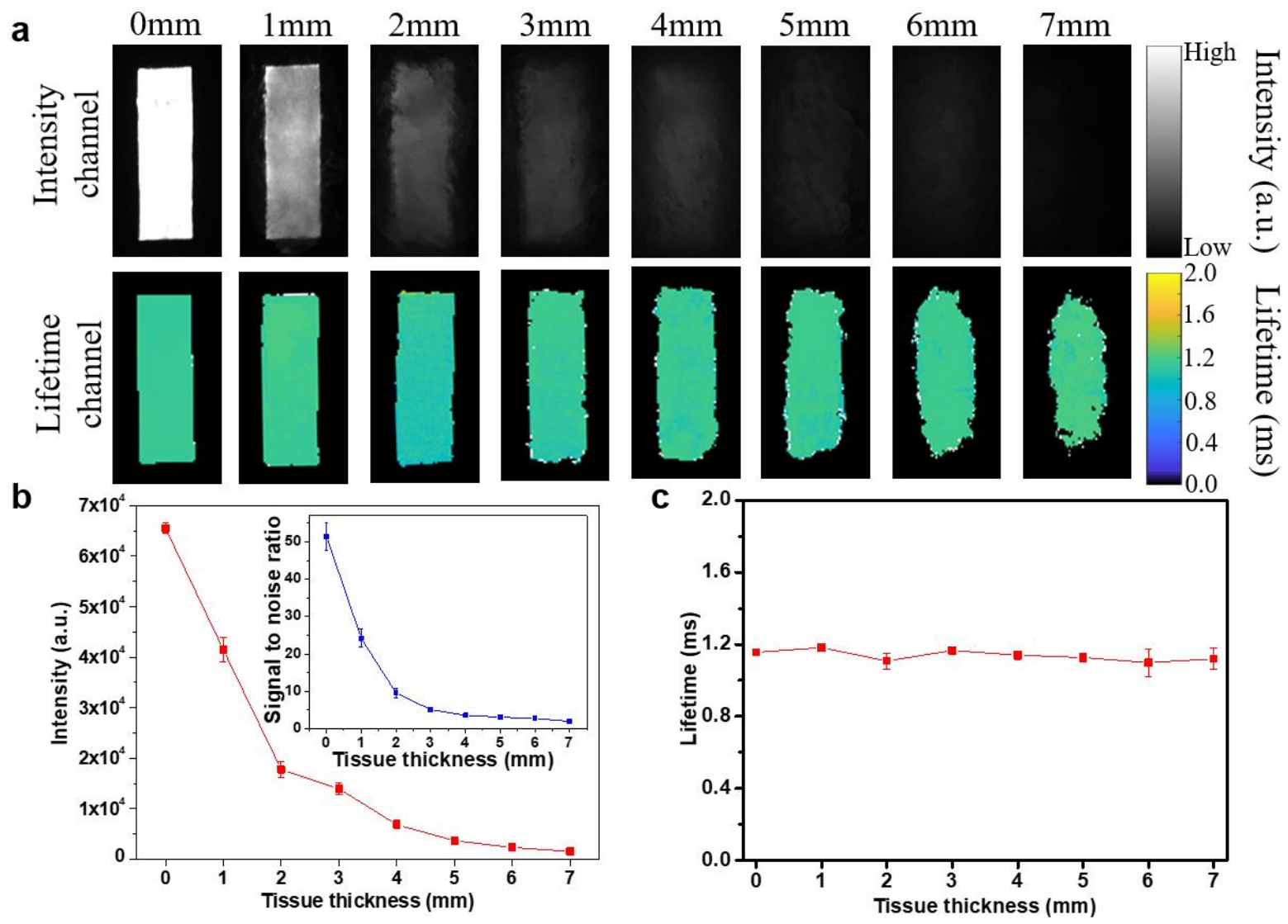

Figure S2. Upconversion luminescence intensity and lifetime imaging through tissues of varying thicknesses. a. Luminesce intensity and lifetime imaging of a strip loaded with PAA-coated core/multishell nanoparticles (with a lifetime of $\tau_{5}$ ) through pork tissue of varying thicknesses. $\mathbf{b}$. Tissue depth-dependent upconversion luminescence intensity and signal-to-noise ratio (SNR) (the inset) $\mathbf{c}$. Tissue depth-independent upconversion luminescence lifetime. A clear depthindependent luminescence lifetime image was acquired versus the distorted luminescence intensity image. Note that a depth of $7 \mathrm{~mm}$, the measured in vivo lifetime was determined to be $1.1 \pm 0.1 \mathrm{~ms}$, comparable to the measured one of $\tau_{5}$-PAA UCNPs $(1.158 \mathrm{~ms})$ at zero-depth. This indicated that temporal upconversion lifetime imaging can be implemented through at least $7 \mathrm{~mm}$ tissue depth. 

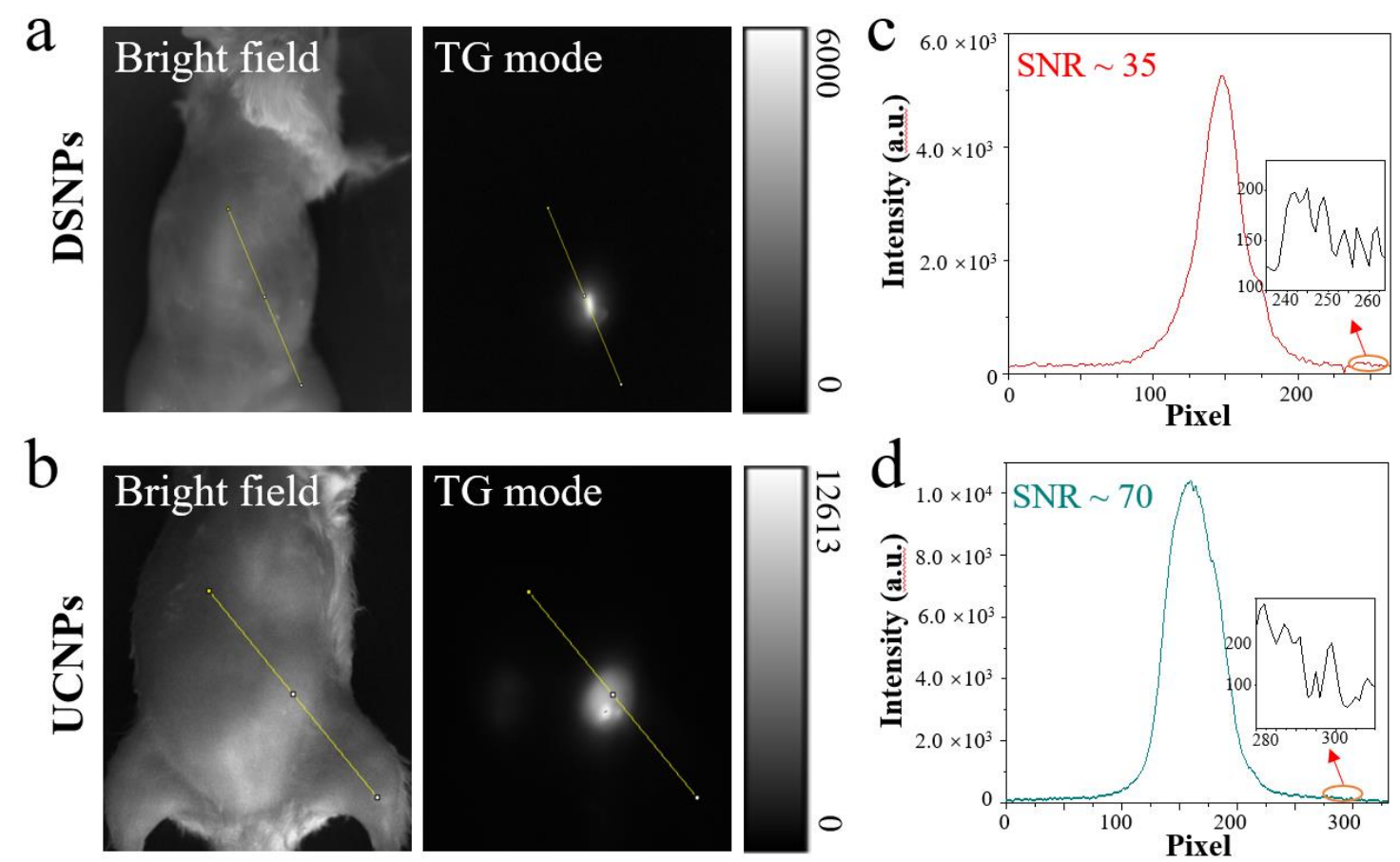

Figure S3. Grayscale images obtained in bright field and time-gated (TG) imaging mode for depilated Kunming mouse after subcutaneous administration with (a) $20 \mu \mathrm{l} \mathrm{NaYF} 4: 10 \% \mathrm{Yb}, 30 \% \mathrm{Nd} @ \mathrm{CaF}_{2}$ down-shifting nanoparticles (DSNPs, lifetime $700 \mu \mathrm{s}$ ), and (b) $20 \mu \mathrm{NaYF}_{4} @ \mathrm{NaYbF}_{4} @ \mathrm{NaYF}_{4}: \mathrm{Yb}^{3+} / \mathrm{Tm}^{3+} @ \mathrm{NaYF}_{4}$ core/shell/shell /shell upconversion nanoparticles (UCNPs, lifetime $\sim 1282 \mu \mathrm{s}$ ) (b). The intensity profile along the line across imaging obtained by employing DSNPs (d) and UCNPs (d). An identical delay time of $10 \mu$ s was applied for both (a) and (b). 


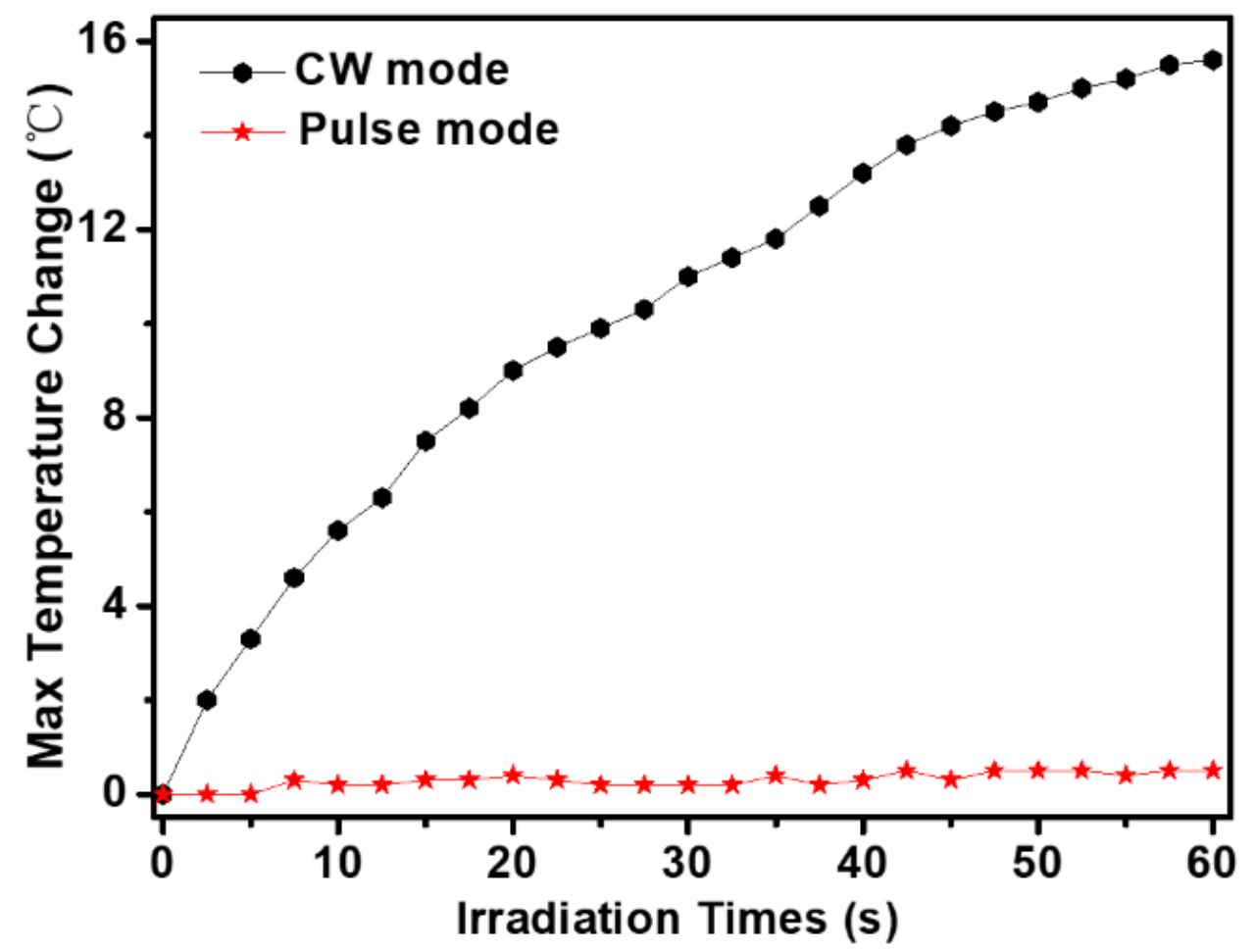

Figure S4. Mouse temperature elevation under pulsed versus continuous-wave laser irradiation at $980 \mathbf{~ n m}$. Laser irradiation of a Kunming mouse at $980 \mathrm{~nm}$ for $60 \mathrm{~s}$ can induce a temperature increase of $16^{\circ} \mathrm{C}$ when running in a continuouswave mode, and near-null temperature escalation when running in a pulsed mode (pulse width $100 \mu \mathrm{s}, 1 \mathrm{KHz}$ ). 

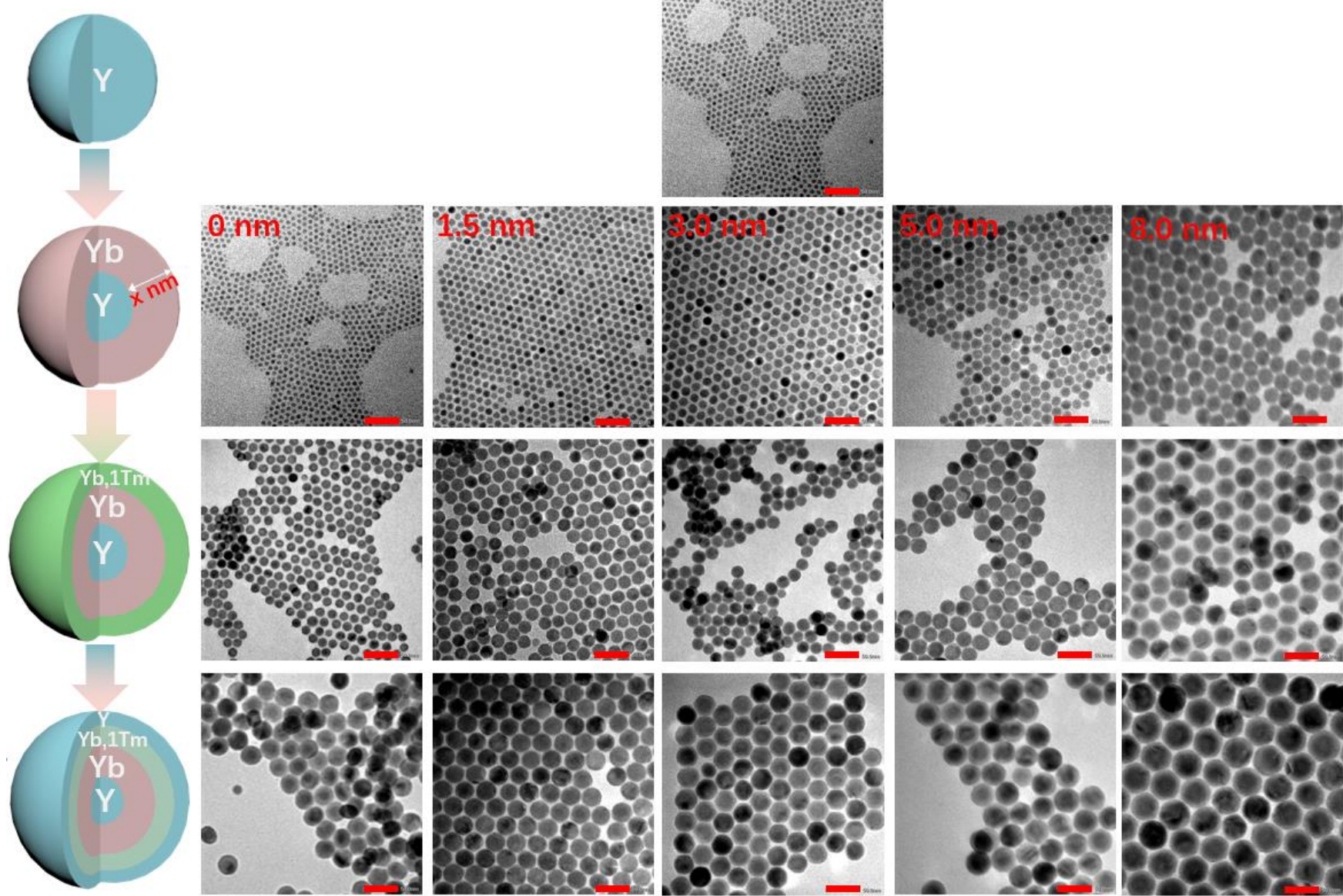

Figure S5. TEM images pertaining to $\mathrm{NaYF}_{4} @ \mathrm{NaYbF}_{4} @ \mathrm{NaYF}_{4}: \mathrm{Yb}^{3+} / \mathbf{T m}^{3+} @ \mathrm{NaYF}_{4}$ nanoparticles with varying thicknesses of the energy migration shell $\left(\mathrm{NaYbF}_{4}\right)$. TEM images of the inert $\mathrm{NaYF}_{4}$ core, the core/shell $\mathrm{NaYF}_{4} @(x$ $\mathrm{nm}) \mathrm{NaYbF}_{4}$ with varying shell thicknesses, the core/shell/shell $\mathrm{NaYF}_{4} @(\mathrm{x} \mathrm{nm}) \mathrm{NaYbF}_{4} @ \mathrm{NaYbF}_{4}: 1 \% \mathrm{Tm}^{3+}$, and the core/shell/shell/shell NaYF $@(x n m) \mathrm{NaYbF}_{4} @ \mathrm{NaYbF}_{4}: 1 \% \mathrm{Tm}^{3+} @ \mathrm{NaYF}_{4}$ nanoparticles $(\mathrm{x}=0,1.5,3.0,5.0$, and 8.0 nm), indicating their uniform morphologies and sizes. 

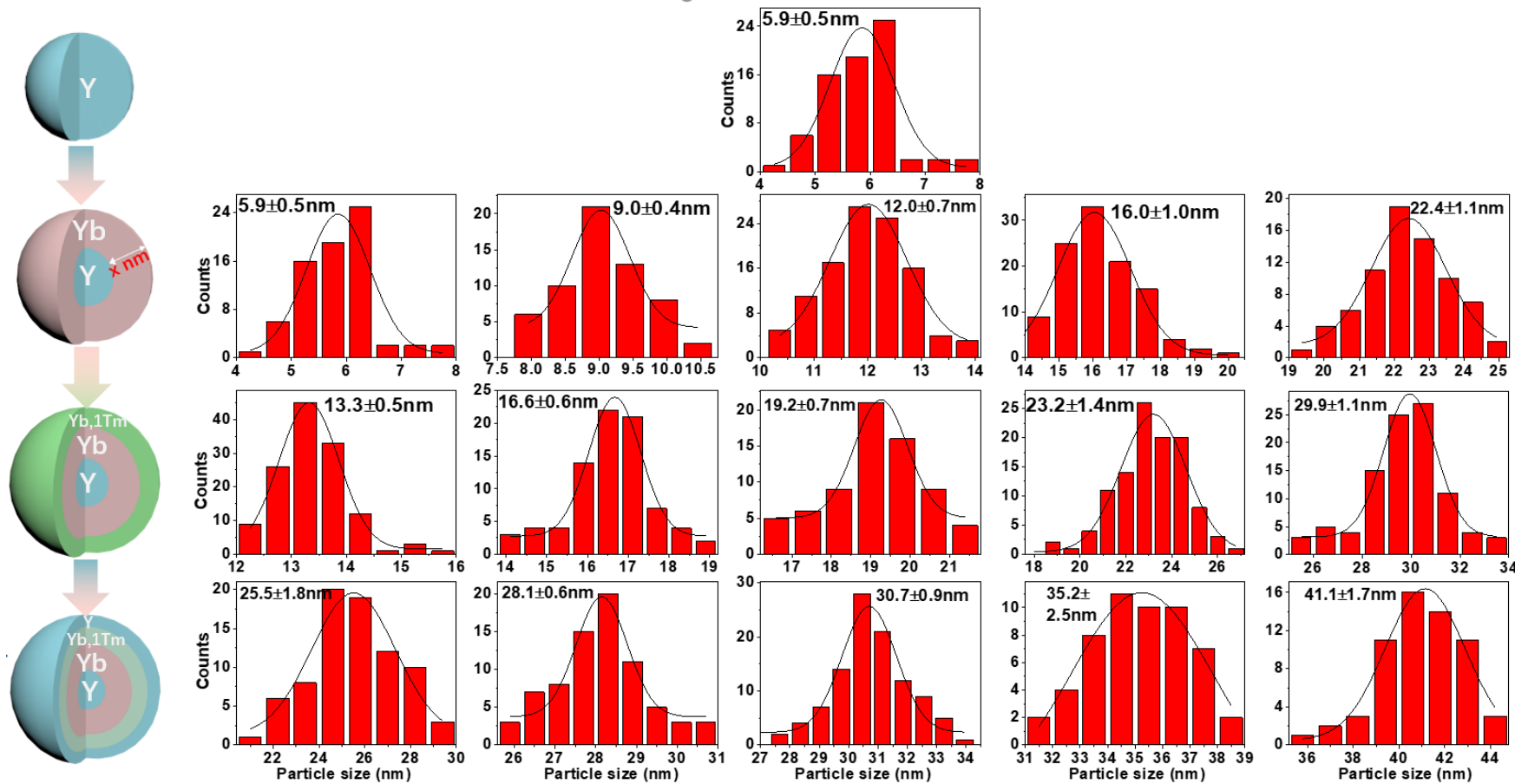

Figure S6. Size histograms pertaining to $\mathrm{NaYF}_{4} @ \mathrm{NaYbF}_{4} @ \mathrm{NaYF}_{4}: \mathrm{Yb}^{3+} / \mathrm{Tm}^{3+} @ \mathrm{NaYF}_{4}$ nanoparticles with varying thicknesses of the energy migration shell $\left(\mathrm{NaYbF}_{4}\right)$. Size histograms of the inert $\mathrm{NaYF}_{4}$ core, the core/shell $\mathrm{NaYF}_{4} @(x$ $\mathrm{nm}) \mathrm{NaYbF}_{4}$ with varying shell thicknesses, the core/shell/shell $\mathrm{NaYF}_{4} @(\mathrm{x} n \mathrm{~nm}) \mathrm{NaYbF}_{4} @ \mathrm{NaYbF}_{4}: 1 \% \mathrm{Tm}^{3+}$, and the core/shell/shell/shell NaYF @ ( $\mathrm{xm}$ ) NaYbF $4 @ \mathrm{NaYbF}_{4}: 1 \% \mathrm{Tm}^{3+} @ \mathrm{NaYF}_{4}$ nanoparticles $(\mathrm{x}=0,1.5,3.0,5.0$, and 8.0 nm). The thickness of the $\mathrm{NaYbF}_{4}: 1 \% \mathrm{Tm}^{3+}$ layer and the outmost inert shell were determined to be about 3.5 and $6.0 \mathrm{~nm}$, respectively. 

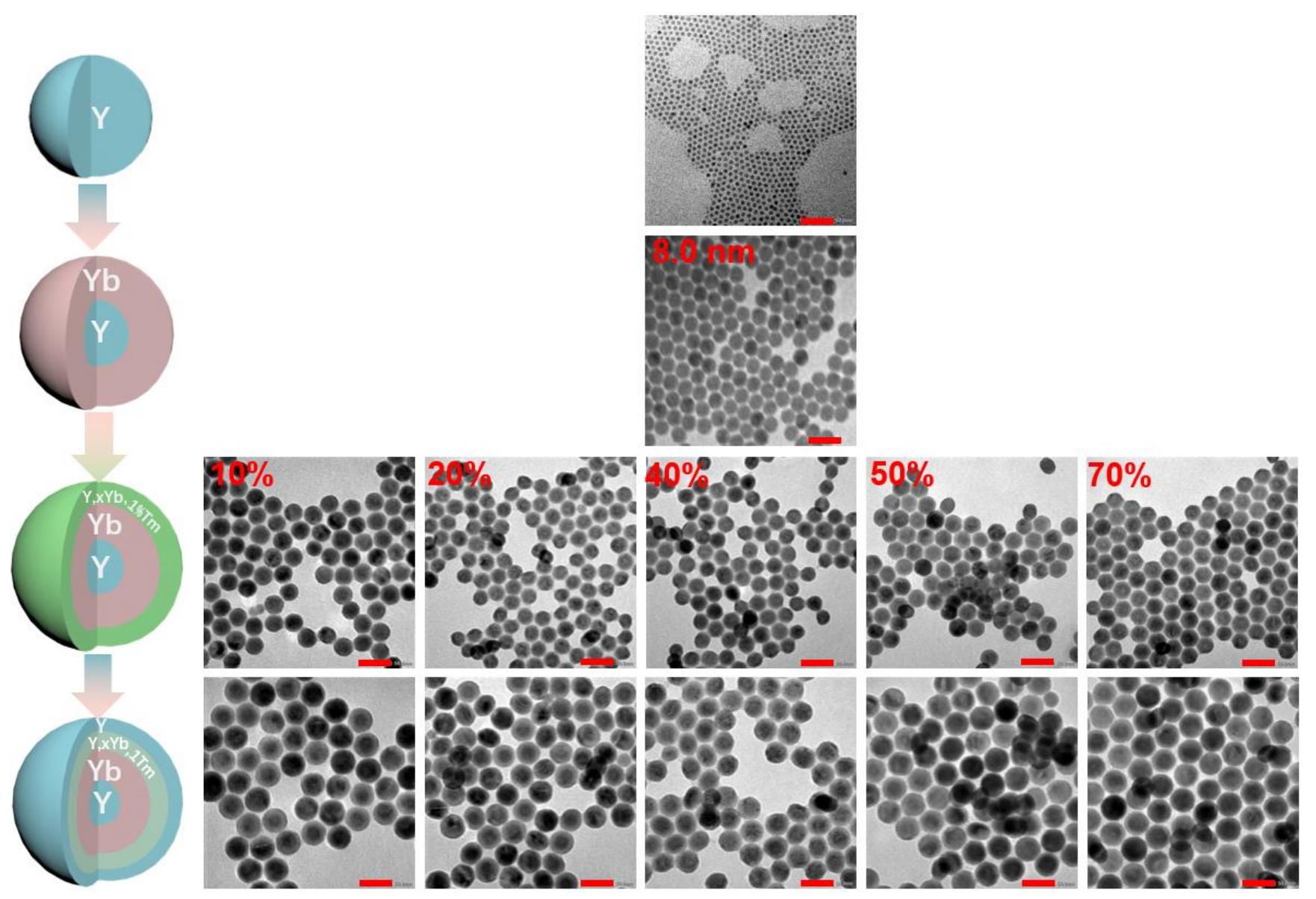

Figure S7. TEM images pertaining to $\mathrm{NaYF}_{4} @ \mathrm{NaYbF}_{4} @ \mathrm{NaYF}_{4}: \mathrm{Yb}^{3+} / \mathrm{Tm}^{3+} @ \mathrm{NaYF}_{4}$ nanoparticles with varying $\mathrm{Yb}^{3+}$ dopant concentration in the upconverting shell $\left(\mathrm{NaYF}_{4}: \mathbf{Y b}^{3+} / \mathbf{T m}^{3+}\right)$. TEM images of the inert $\mathrm{NaYF}_{4}$ core, the core/shell $\mathrm{NaYF}_{4} @ \mathrm{NaYbF}_{4}$ with a shell thickness of $8 \mathrm{~nm}$, the core/shell/shell $\mathrm{NaYF}_{4} @ \mathrm{NaYbF}_{4} @ \mathrm{NaYF}_{4}: \mathrm{x}^{\%} \mathrm{Yb}^{3+}, 1 \%$ $\mathrm{Tm}^{3+}$, and the core/shell/shell/shell $\mathrm{NaYF}_{4} @ \mathrm{NaYbF}_{4} @ \mathrm{NaYF}_{4}: \mathrm{x} \% \mathrm{Yb}^{3+}, 1 \% \mathrm{Tm}^{3+} @ \mathrm{NaYF}_{4}$ nanoparticles (x=10, 20, 40, 50, and 70). These images indicate that all these nanoparticles have uniform morphology and size. 

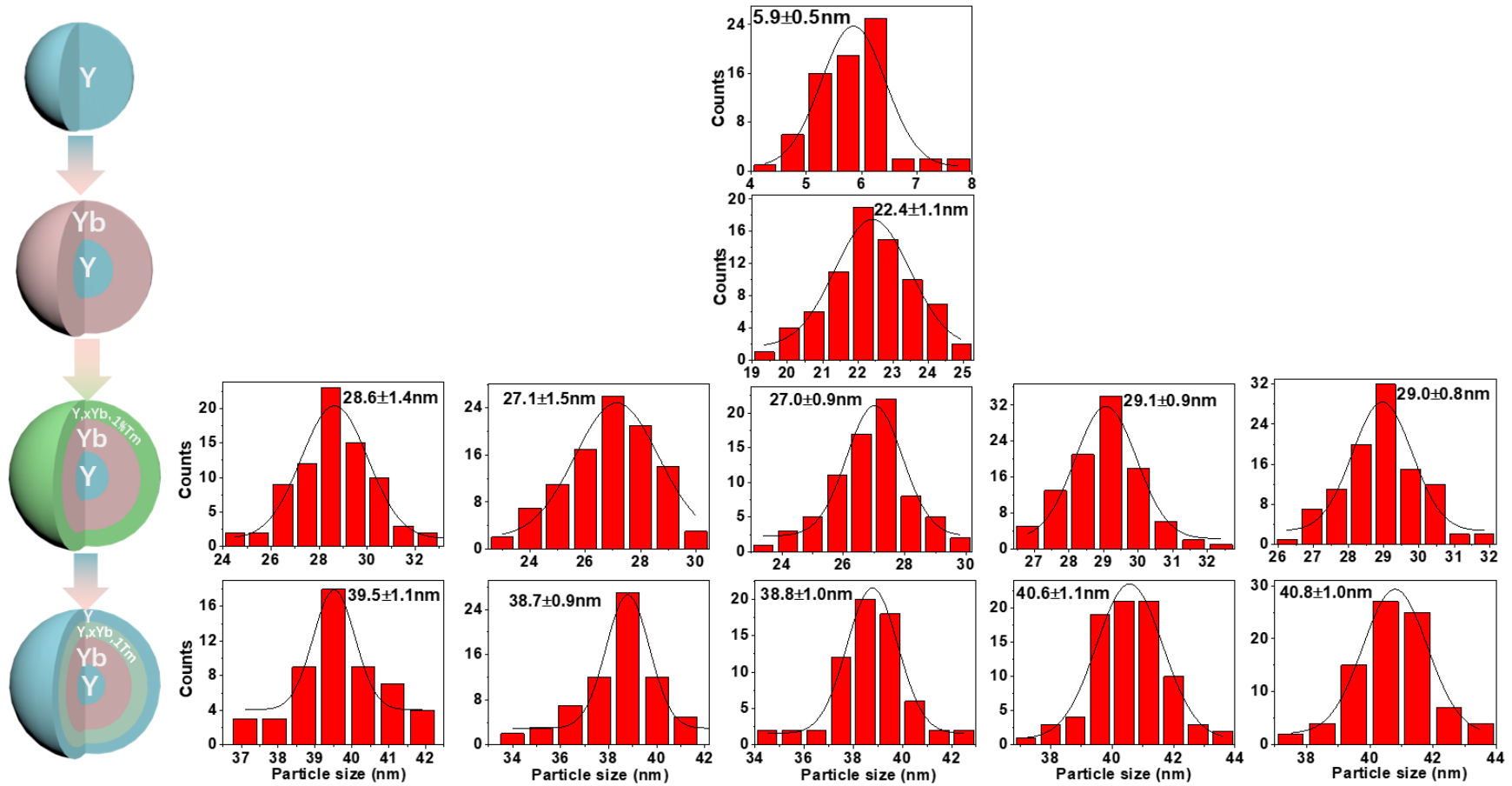

Figure S8. Size histograms pertaining to $\mathrm{NaYF}_{4} @ \mathrm{NaYbF}_{4} @ \mathrm{NaYF}_{4}: \mathrm{Yb}^{3+} / \mathrm{Tm}^{3+} @ \mathrm{NaYF}_{4}$ nanoparticles with varying $\mathbf{Y b}^{3+}$ dopant concentration in the upconverting shell $\left(\mathrm{NaYF}_{4}: \mathbf{Y b}^{3+} / \mathbf{T m}^{3+}\right)$. Size histograms of the inert $\mathrm{NaYF}_{4}$ core, the core/shell $\mathrm{NaYF}_{4} @ \mathrm{NaYbF}_{4}$ with a shell thickness of 8 nm, the core/shell/shell NaYF${ }_{4} @ \mathrm{NaYbF}_{4} @ \mathrm{NaYF}_{4}: \mathrm{x} \% \mathrm{Yb}^{3+}, 1 \%$ $\mathrm{Tm}^{3+}$, and the core/shell/shell/shell NaYF $4 @ \mathrm{NaYbF}_{4} @ \mathrm{NaYF}_{4}: \mathrm{x} \% \mathrm{Yb}^{3+}, 1 \% \mathrm{Tm}^{3+} @ \mathrm{NaYF}_{4}$ nanoparticles $(\mathrm{x}=10,20,40$, 50 , and 70). The thicknesses of the $\mathrm{NaYF}_{4}: \mathrm{x}^{0} \mathrm{Yb}^{3+}, 1 \% \mathrm{Tm}^{3+}(\mathrm{x}=10,20,40,50$, and 70$)$ layer was determined to be $3.5 \mathrm{~nm}$, while the outmost inert $\mathrm{NaYF}_{4}$ layer was calculated to be $6.0 \mathrm{~nm}$, respectively. 


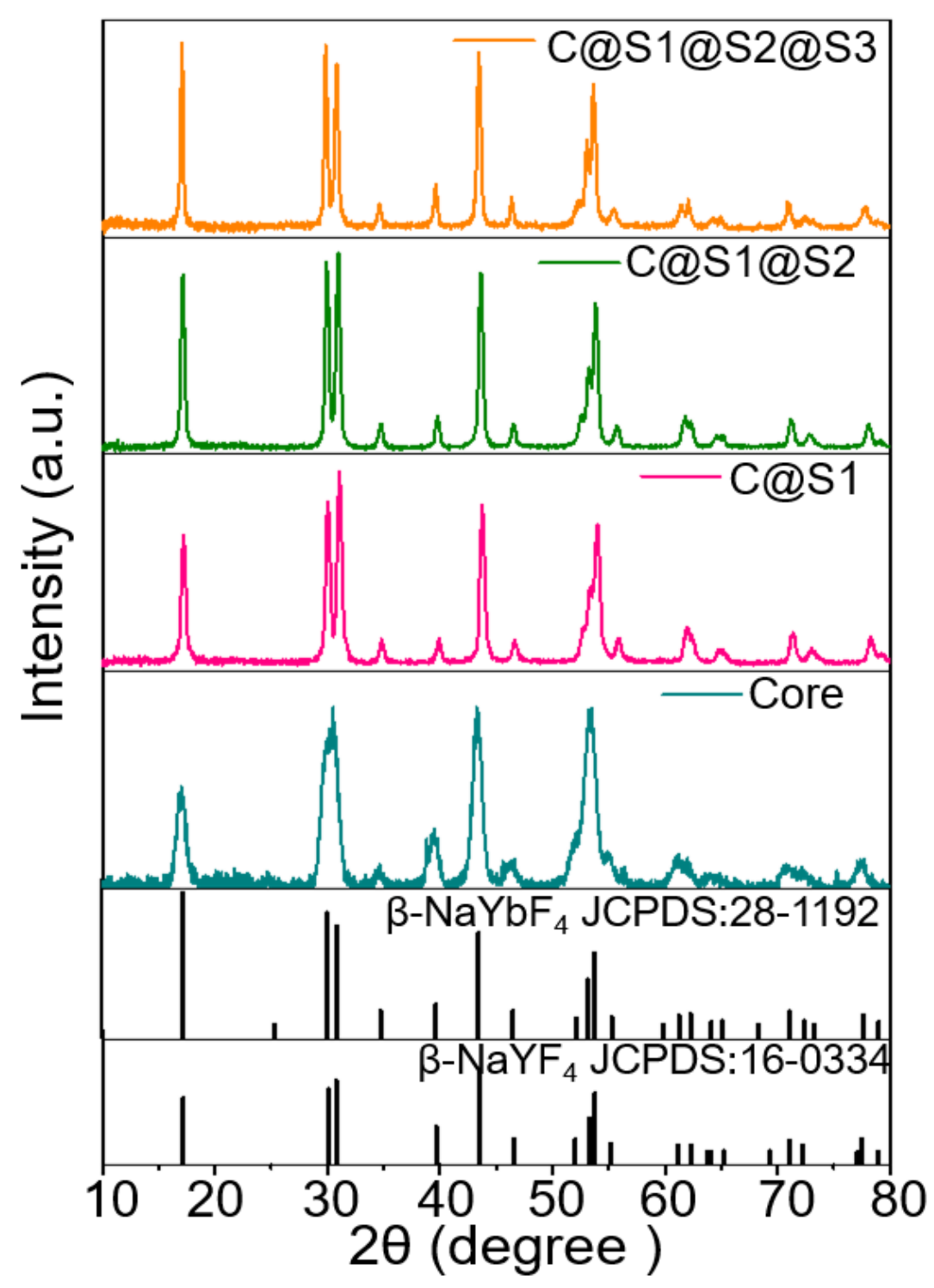

Figure S9. XRD patterns pertaining to $\mathrm{NaYF}_{4} @ \mathrm{NaYbF}_{4} @ \mathrm{NaYF}_{4}: \mathrm{Yb}^{3+} / \mathrm{Tm}^{3+} @ \mathrm{NaYF}_{4}$ nanoparticles in Figure 2b. The x-ray diffraction (XRD) patterns of the inert $\mathrm{NaYF}_{4}$ core (denoted as core), the core/ shell $\mathrm{NaYF}_{4} @ \mathrm{NaYbF}_{4}($ denoted as core@S1), the core/shell/shell $\mathrm{NaYF}_{4} @ \mathrm{NaYbF}_{4} @ \mathrm{NaYF}_{4}: \mathrm{Yb}^{3+} / \mathrm{Tm}^{3+}$ (denoted as core@S1@S2), and the core/shell/shell/shell NaYF $@ \mathrm{NaYbF}_{4} @ \mathrm{NaYF}_{4}: \mathrm{Yb}^{3+} / \mathrm{Tm}^{3+} @ \mathrm{NaYF}_{4}$ (denoted as core@S1@S2@S3)nanoparticles.The standard XRD patterns of $\beta-\mathrm{NaYF}_{4}$ (JCPDS 16-0334) and $\beta-\mathrm{NaYbF}_{4}$ (JCPDS 28-1192) are included for references. The $\mathrm{XRD}$ patterns indicate all these nanoparticles are of hexagonal crystallographic phase. 


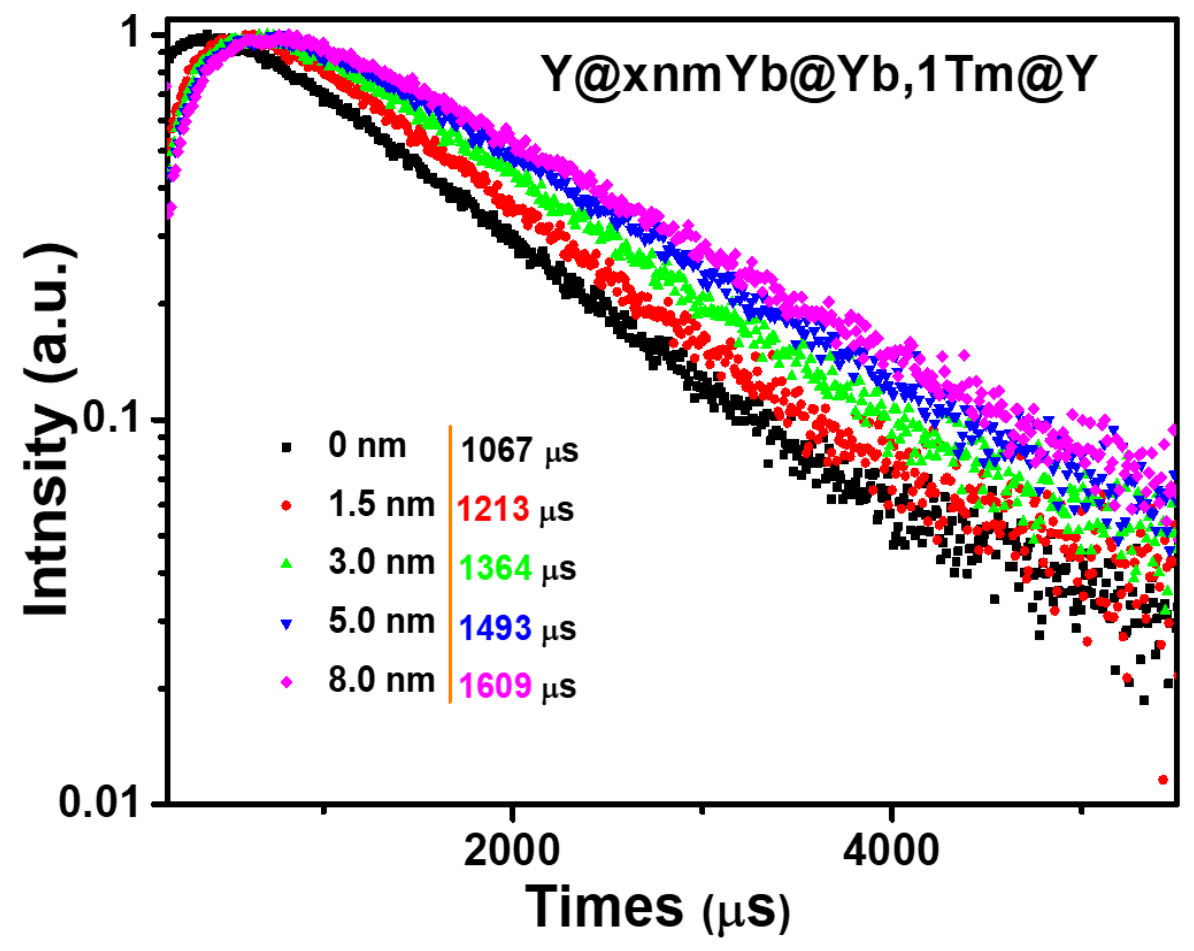

Figure S10. The downshifting luminescence decay profiles of $980 \mathrm{~nm}$ emitted by $\mathrm{NaYF}_{4} @(\mathrm{x} \mathrm{nm}) \mathrm{NaYbF}_{4} @ \mathrm{NaYF}_{4}$ : $\mathrm{Yb}^{3+} / \mathrm{Tm}^{3+} @ \mathrm{NaYF}_{4}$ nanoparticle $(\mathrm{x}=0 \mathrm{~nm}, 1.5 \mathrm{~nm}, 3.0 \mathrm{~nm}, 5.0 \mathrm{~nm}, 8.0 \mathrm{~nm})$ under $808 \mathrm{~nm}$ excitation. 

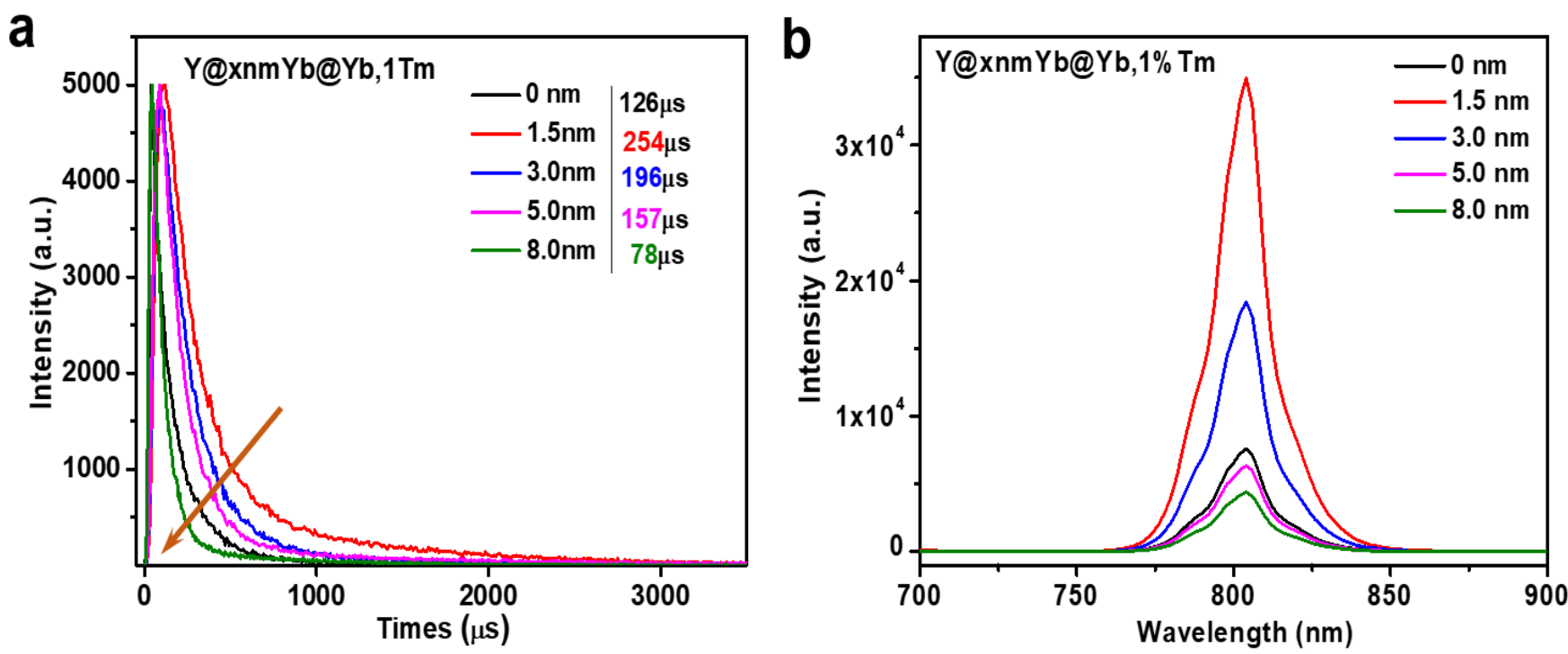

Figure S11. Upconversion luminescence lifetime and intensity of $\mathrm{NaYF}_{4} @ \mathrm{NaYbF}_{4} @ \mathrm{NaYF}_{4}: \mathrm{Yb}^{3+} / \mathbf{T m}^{3+}$ nanoparticles with varying energy migration shell $\left(\mathrm{NaYbF}_{4}\right)$ thicknesses. Measured upconversion luminescence lifetime (a) and intensity $(\mathbf{b})$ at $808 \mathrm{~nm}$ for $\mathrm{NaYF}_{4} @ \mathrm{NaYbF}_{4} @ \mathrm{NaYbF}_{4}: 1 \% \mathrm{Tm}^{3+}$ with tuneable thickness of the energy migration (EM) layer of $\mathrm{NaYbF}_{4}$ from $0,1.5,3.0,5.0$ and $8.0 \mathrm{~nm}$, respectively. An escalation of the EM thickness from 0 to $1.5 \mathrm{~nm}$ results in an increase in both the lifetime (from 126 to $254 \mu$ s) and the intensity (by about 1.5 fold). This clearly indicate the existence of EM process. However, both the upconversion luminescence lifetime and the upconversion luminescence intensity were gradually diminished when further escalating the EM layer thickness from 1.5 to 3.0, 5.0, and $8.0 \mathrm{~nm}$. This can possibly be ascribed that the harvested energy in the EM layer is more liable to migrate into surface quenchers (ligands, surface crystal defects, and solvents, etc.) through $\mathrm{Yb}^{3+}$ sub-lattice, than be utilized for producing upconversion luminescence in the $\mathrm{NaYbF}_{4}: 1 \% \mathrm{Tm}^{3+}$ layer. This is reasonable, as the outmost $\mathrm{NaYbF}_{4}: 1 \% \mathrm{Tm}^{3+}$ layer is enriched with $\mathrm{Yb}^{3+}$ ions, which are directly exposed to the surrounding environment without any protection. 

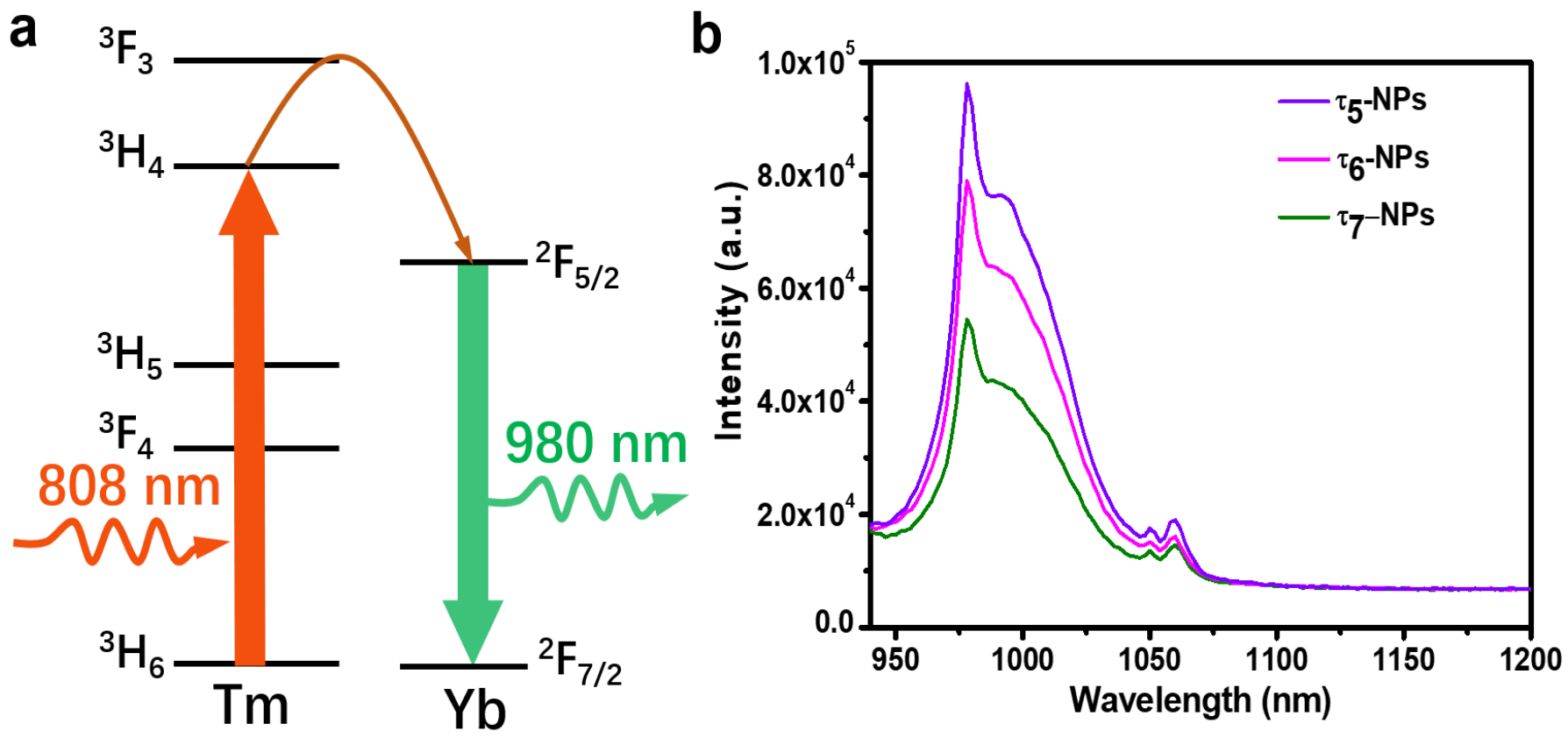

Figure S12. Back energy transfer process from $\mathrm{Tm}^{3+}$ to $\mathrm{Yb}^{3+}$ ions. a. Simplified energy level diagrams of $\mathrm{Tm}^{3+}$ and $\mathrm{Yb}^{3+}$ ions, illustrating the back energy transfer process from $\mathrm{Tm}^{3+}$ to $\mathrm{Yb}^{3+}$ ions. b. Down-shifting luminescence of the core/multishell $\mathrm{NaYF}_{4} @ \mathrm{NaYbF}_{4} @ \mathrm{NaYF}_{4}: \mathrm{Yb}^{3+} / 1 \% \mathrm{Tm}^{3+} @ \mathrm{NaYF}_{4}$ nanoparticles with $\mathrm{Yb}^{3+}$ dopant concentration of $99 \%$ (lifetime $\tau_{5}$ ), $70 \%$ (lifetime $\tau_{6}$ ), and 50\% (lifetime $\tau_{7}$ ) in the upconverting layer of $\mathrm{NaYF}_{4}: \mathrm{Yb}^{3+} / 1 \% \mathrm{Tm}^{3+}$. When performing a direct excitation of $\mathrm{Tm}^{3+}$ in the core/multishell nanoparticles using light at $808 \mathrm{~nm}$, luminescence from $\mathrm{Yb}^{3+}$ ions were clearly observed, and declined with a decrease of $\mathrm{Yb}^{3+}$ concentration. This clearly verify the existence of $\mathrm{Yb}^{3+}$-concentration dependent back energy transfer process in the upconverting layer. 

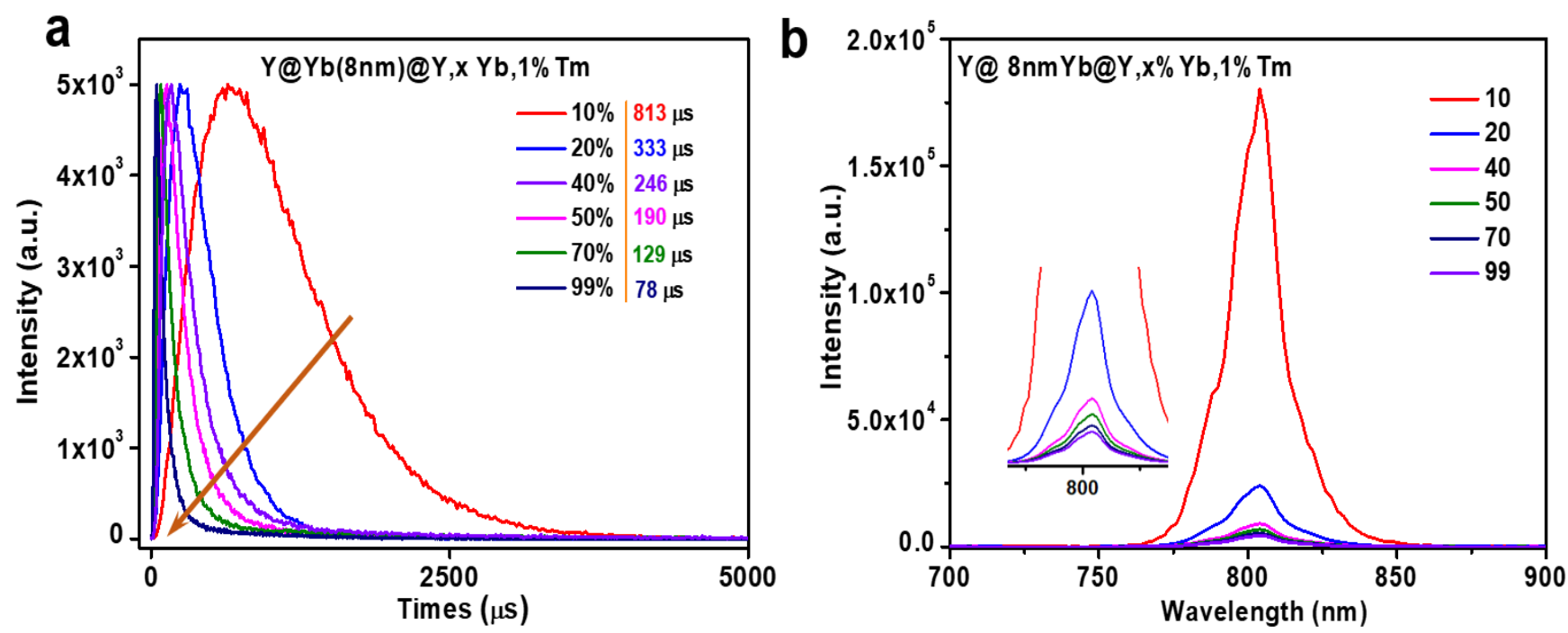

Figure S13. Upconversion luminescence lifetime and intensity for $\mathrm{NaYF}_{4} @ \mathrm{NaYbF}_{4} @ \mathrm{NaYF}_{4}: \mathbf{Y b}^{3+} / \mathrm{Tm}^{3+}$ nanoparticles with varying $\mathrm{Yb}^{3+}$ dopant concentration in the upconverting shell $\left(\mathrm{NaYF}_{4}: \mathbf{Y b}^{3+} / \mathbf{T m}^{3+}\right)$. The upconversion luminescence lifetime (a) and intensity $(\mathbf{b})\left(\right.$ at $808 \mathrm{~nm}$ ) of the $\mathrm{NaYF}_{4} @ \mathrm{NaYbF}_{4} @ \mathrm{NaYF}_{4}: \mathrm{x}^{2} \mathrm{Yb}^{3+}, 1 \% \mathrm{Tm}^{3+}$ nanoparticles $\left(\mathrm{x}=10,20,40,50\right.$, and 70). An increase of $\mathrm{Yb}^{3+}$ dopant concentrations result in lifetime shortening and intensity decreasing. 

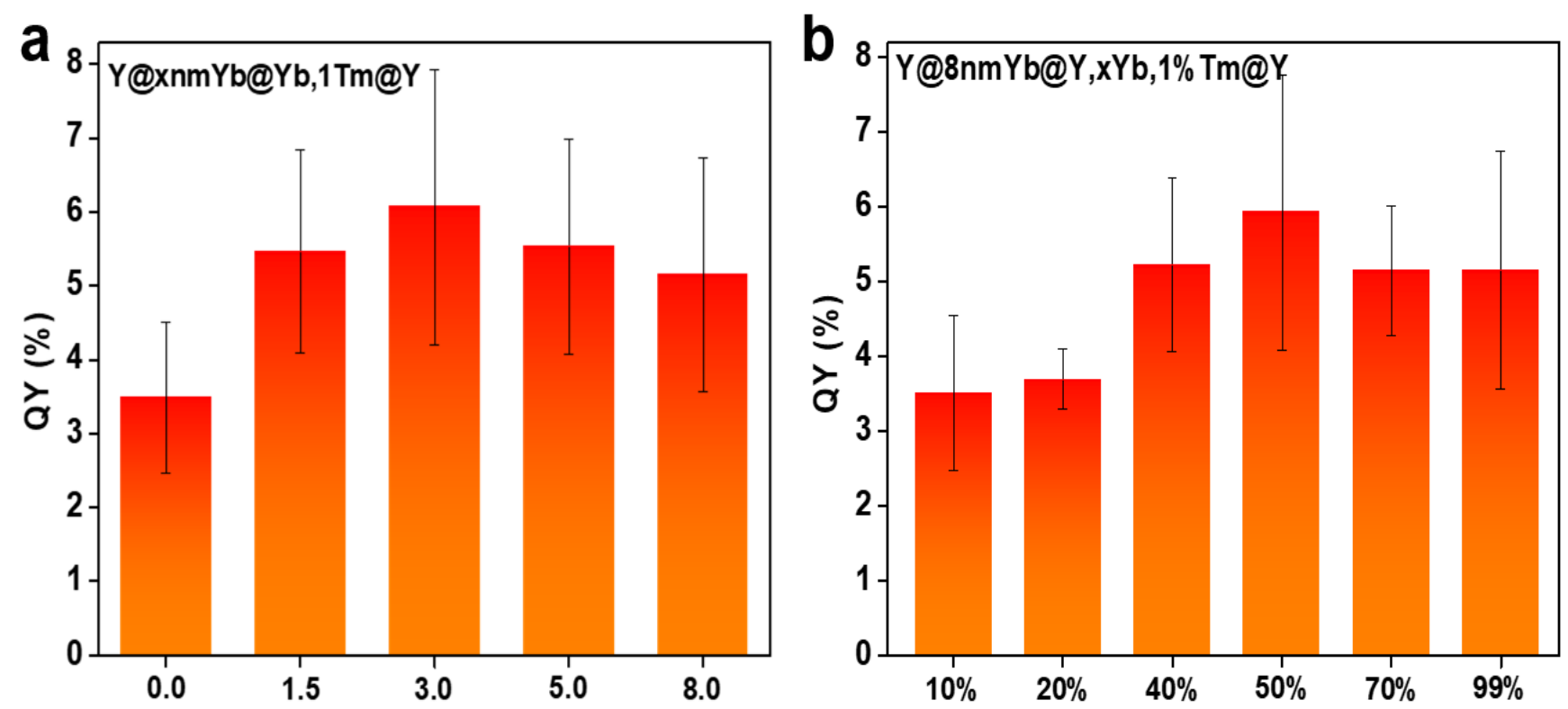

Figure S14. Absolute quantum yields of tetradomain core/multishell $\mathrm{NaYF}_{4} @ \mathrm{NaYbF}_{4} @ \mathrm{NaYF}_{4}: \mathrm{Yb}^{3+} / \mathrm{Tm}^{3+} @ \mathrm{NaYF}_{4}$ upconversion nanoparticles. Measured absolute upconversion quantum yields of $\mathrm{NaYF}_{4} @ \mathrm{NaYbF}_{4} @ \mathrm{NaYF}_{4}: \mathrm{Yb}^{3+} / \mathrm{Tm}^{3+}$ @ $\mathrm{NaYF}_{4}$ nanoparticles (for the luminescence band at $808 \mathrm{~nm}$ ) with (a) varying energy migration (EM) layer thickness $\left(\mathrm{NaYbF}_{4}\right.$ shell, 0, 1.5, 3.0, 5.0 and $\left.8.0 \mathrm{~nm}\right)$ and $(\mathbf{b})$ varying dopant concentrations of $\mathrm{Yb}^{3+}$ ions in the energy transfer upconversion (ETU) layer $\left(\mathrm{NaYF}_{4}: \mathrm{Yb}^{3+} / \mathrm{Tm}^{3+}\right.$ shell, 10\%, 20\%, 40\%, 50\%, 70\%, and 99\%). Excitation at $980 \mathrm{~nm}$ with a power density of $0.11 \mathrm{~W} / \mathrm{cm}^{2}$. This power density is comparable to that utilized for upconverison luminescence imaging $\left(0.12 \mathrm{~W} / \mathrm{cm}^{2}\right)$. 


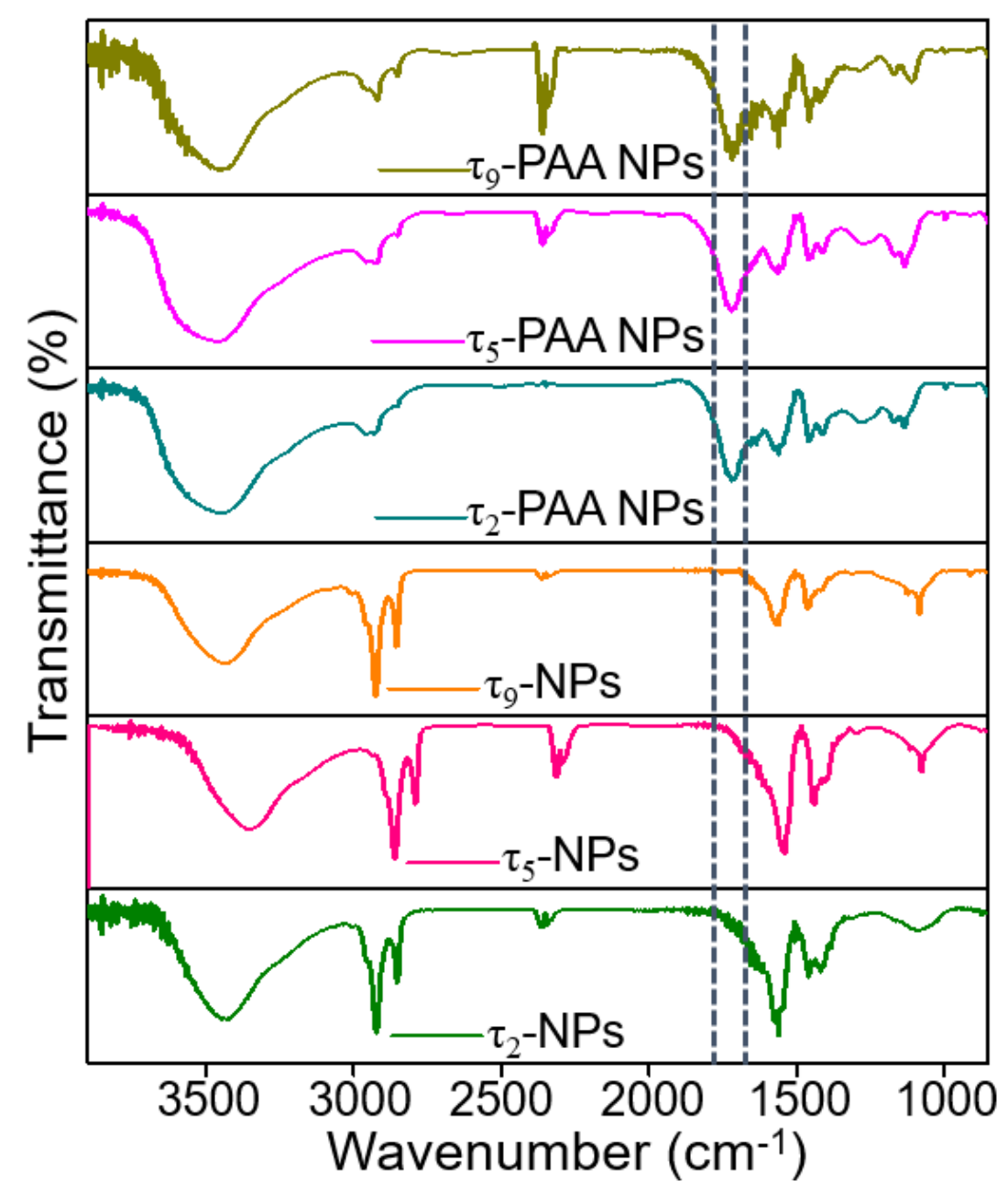

Figure S15. Fourier transform infrared (FTIR) spectra of $\mathrm{NaYF}_{4} @ \mathrm{NaYbF}_{4} @ \mathrm{NaYF}_{4}: \mathrm{Yb}^{3+} / \mathrm{Tm}^{3+} @ \mathrm{NaYF}_{4}$ upconversion nanoparticles before and after PAA surface modifications. FTIR spectra of three representative core/multishell nanoparticles with lifetimes of $\tau_{2^{-}}, \tau_{5^{-}}$and $\tau_{9}$ (please refer to Table $\mathrm{S} 1$ for detailed nanoparticle composition and structure) before and after ligand exchange with polyacrylic acid (PAA, $\mathrm{mw}=15000$ ). As one can see, a new band at $1721 \mathrm{~cm}^{-1}$ appears (labelled in dash line) for all three nanoparticles after ligand exchange, which arises from the $\mathrm{C}=\mathrm{O}$ vibration from the carboxyl groups of PAA. This observation indicates a successful ligand exchange. 

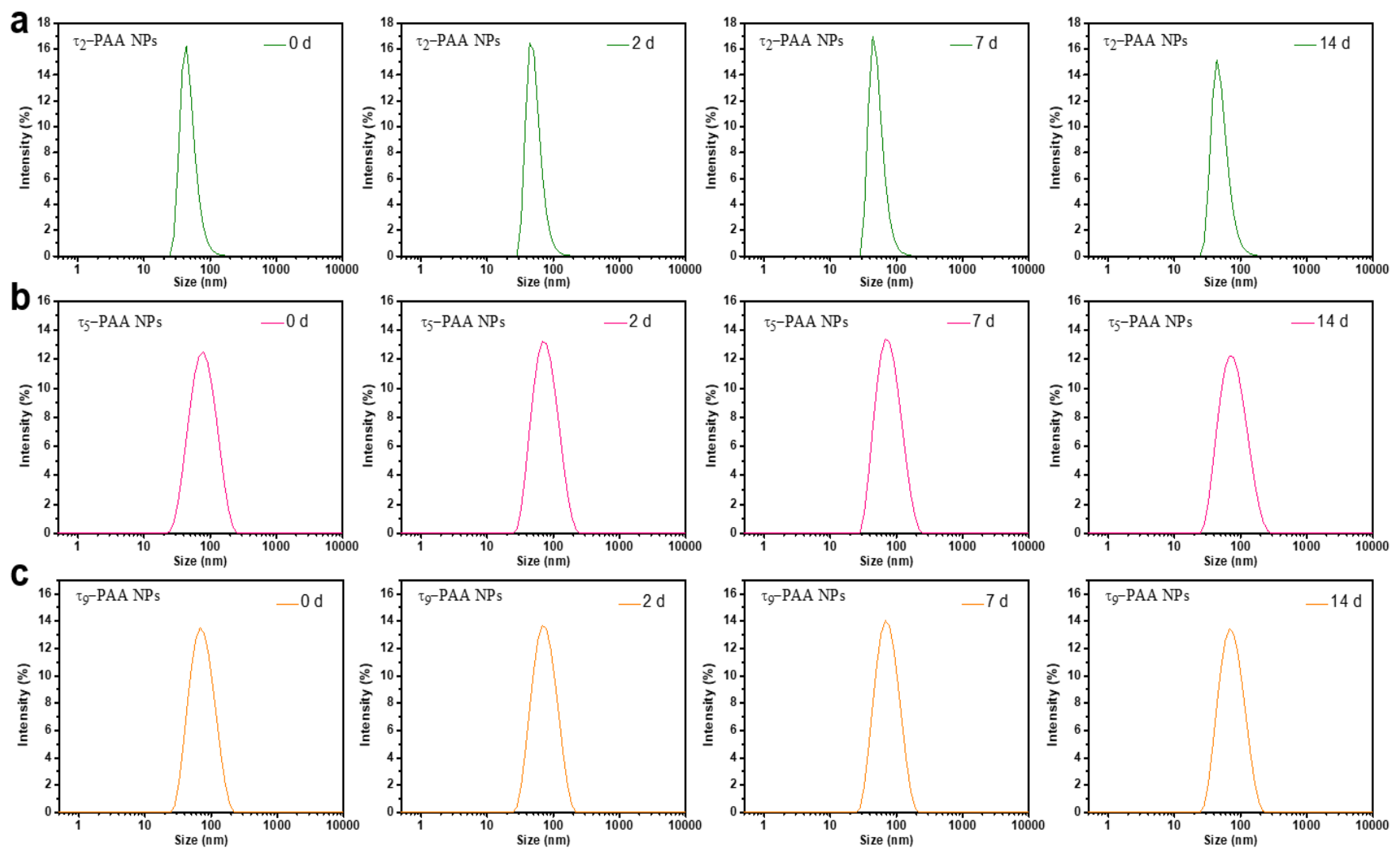

Figure S16. Colloidal stabilities of PAA-coated $\mathrm{NaYF}_{4} @ \mathrm{NaYbF}_{4} @ \mathrm{NaYF}_{4}: \mathrm{Yb}^{3+} / \mathbf{T m}^{3+} @ \mathrm{NaYF}_{4}$ upconversion nanoparticles in PBS. Dynamic light scattering measurements of the three imaging-used core/multishell nanoparticles with lifetimes of $\tau_{2^{-}}, \tau_{5^{-}}$and $\tau_{9}$ (please refer to Table S1 for detailed nanoparticle composition and structure). The hydrodynamic (HD) sizes in PBS solution remain quite stable over a long period of 14 days, indicating their high colloidal stabilities. 

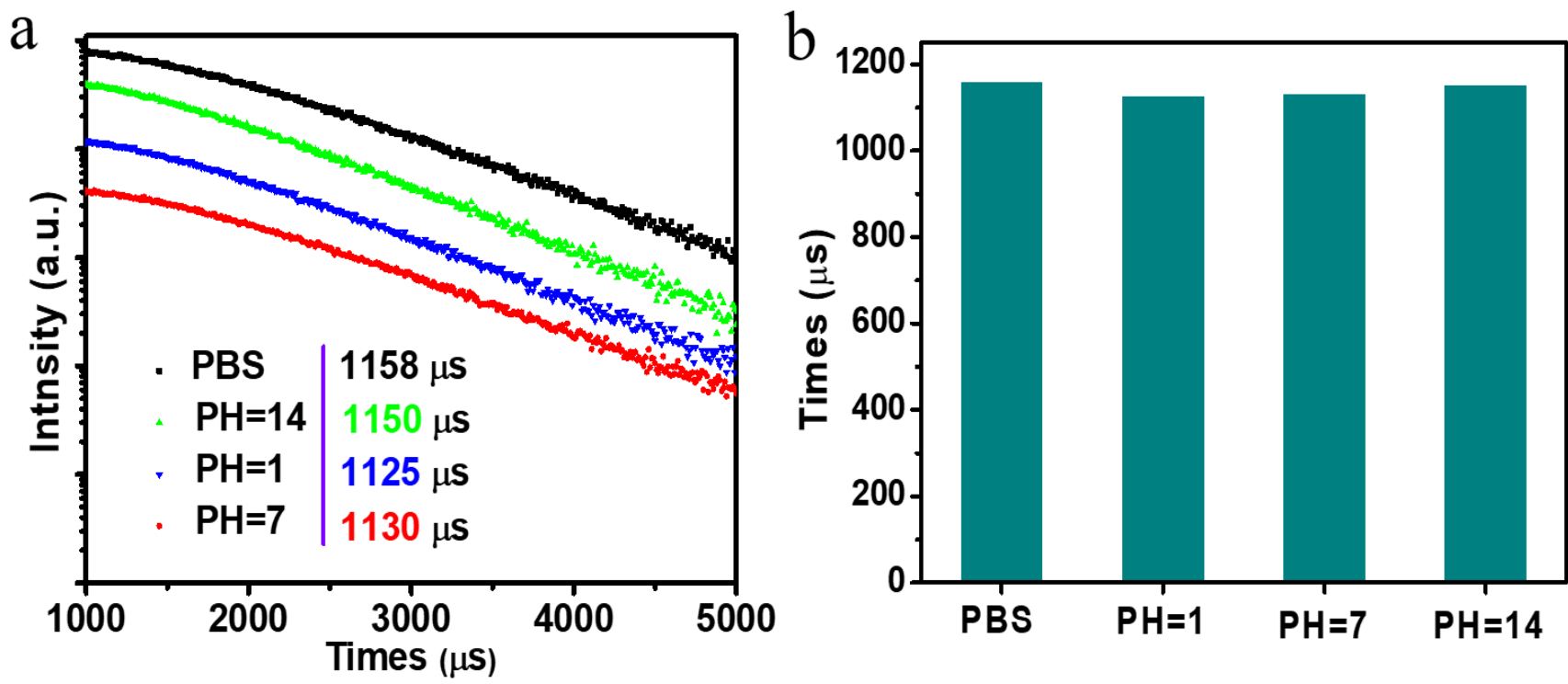

Figure S17. (a) Luminescence decay curves of core/multishell $\tau_{5}$-UCNPs in $\mathrm{pH}$-varying aqueous media and PBS. They were displaced vertically for better visualization. (b) Measured lifetime values of $\tau_{s^{-}}$UCNPs from the experimental data in (a). 

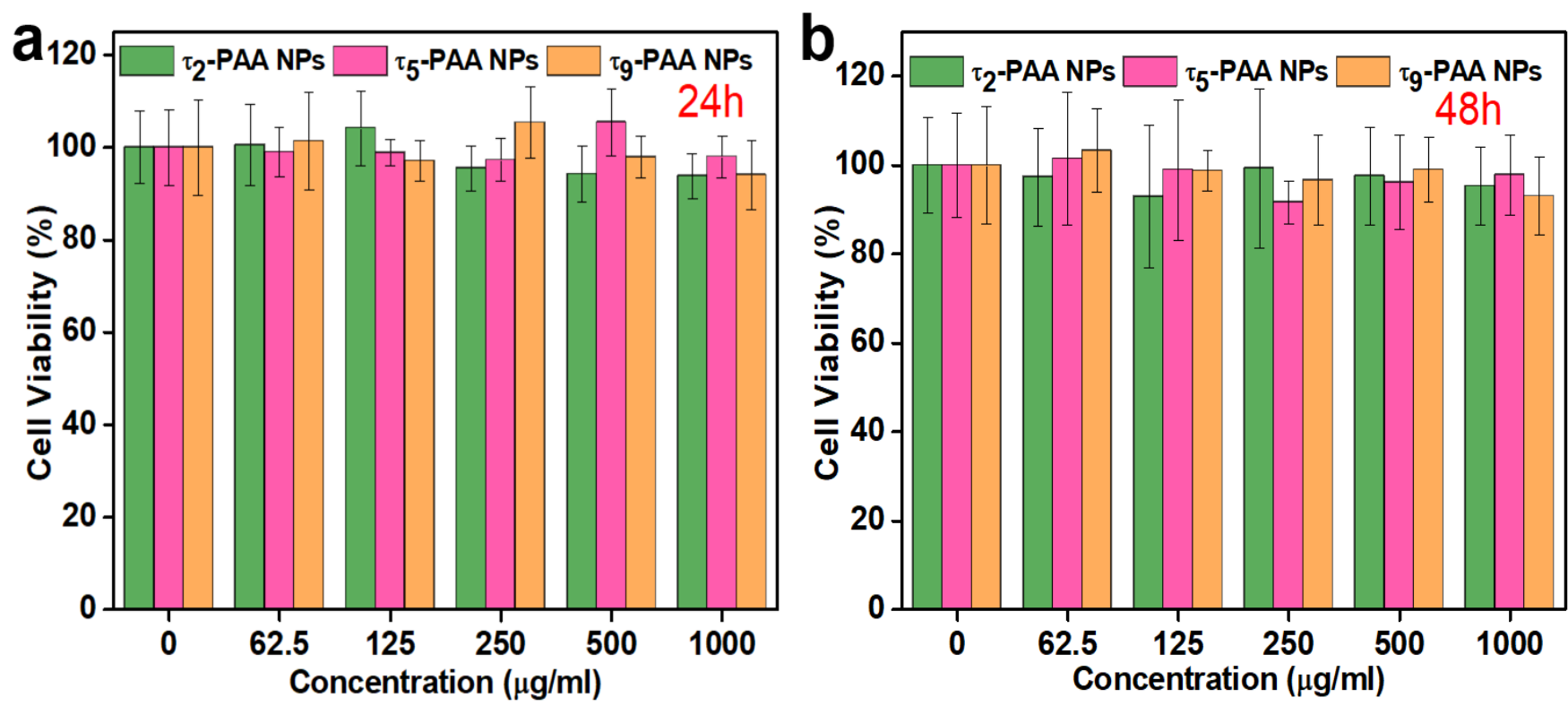

Figure S18. Cytotoxic studies of PAA-coated $\mathrm{NaYF}_{4} @ \mathrm{NaYbF}_{4} @ \mathrm{NaYF}_{4}: \mathrm{Yb}^{3+} / \mathrm{Tm}^{3+} @ \mathrm{NaYF}_{4}$ upconversion nanoparticles. MTT [3-(4, 5-dimethylthiazol-2-yl)-2, 5-diphenyltetrazolium bromide] assay was utilized to evaluate the toxicities of imaging-used core/multishell nanoparticles (with lifetimes of $\tau_{2}, \tau_{5}$ and $\tau_{9}$ ) over (a) $24 \mathrm{~h}$ and (b) $48 \mathrm{~h}$. The viabilities of HeLa cell remained over $90 \%$ even at a high nanoparticle concentration of $1000 \mu \mathrm{g} / \mathrm{ml}$ for $48 \mathrm{~h}$, indicating low cytotoxicities of these PAA-coated core/multishell nanoparticles. 

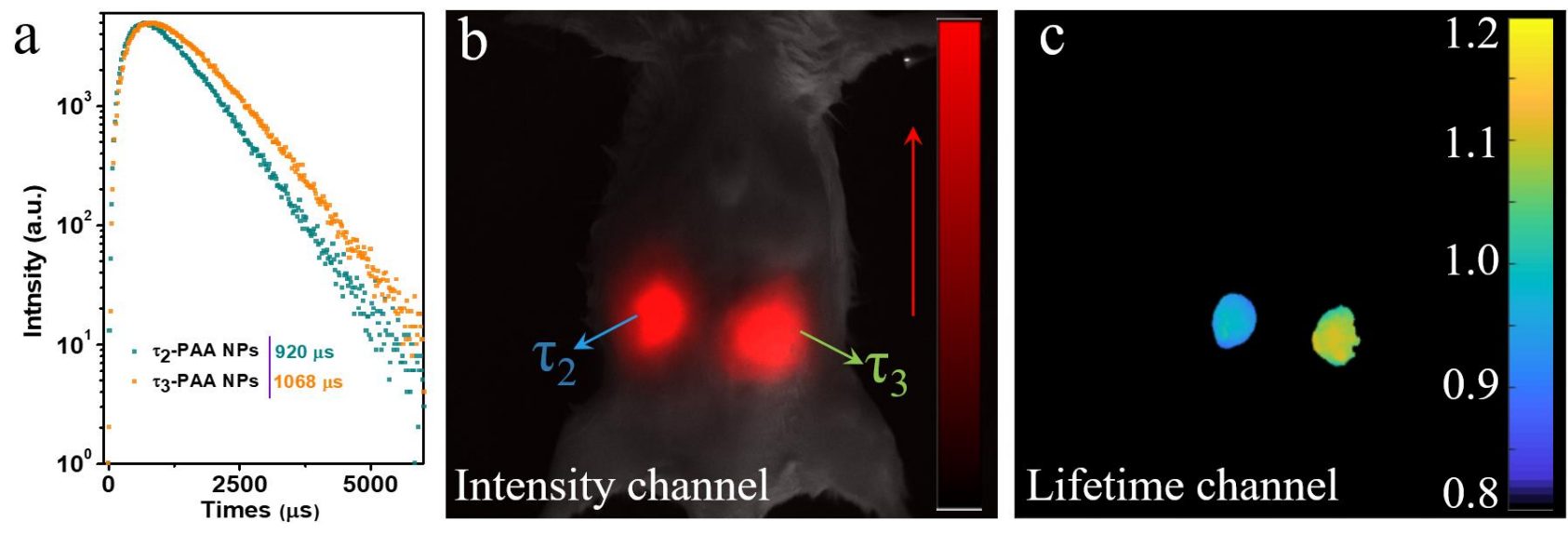

Figure S19. The in vivo multiplexed lifetime imaging of two UCNPs with close lifetimes. (a) Measured upconversion luminescence decay profiles of PAA-coated core/multishell nanoparticles with lifetimes of $\tau_{2}$, $\tau_{3}$ (aqueous dispersion). Upconversion luminescence intensity (b) and lifetime (c) imaging of PAA-coated core/multishell nanoparticles with lifetimes of $\tau_{2}$ and $\tau_{3}$ in a Kunming mouse (subcutaneous injection of these nanoparticles into abdomen). 
Table S1. Compiled upconversion luminescence lifetimes (at $808 \mathrm{~nm}$ ) and structure compostion pertaining to $\mathrm{NaYF}_{4} @ \mathrm{NaYbF}_{4} @ \mathrm{NaYF}_{4}: \mathrm{Yb}^{3+} / \mathrm{Tm}^{3+} @ \mathrm{NaYF}_{4}$ nanoparticles.

\begin{tabular}{|c|c|c|c|c|}
\hline $\begin{array}{c}\text { Structure } \\
\text { composition }\end{array}$ & $\begin{array}{l}\text { Sample } \\
\text { name }\end{array}$ & $\begin{array}{c}\text { Thinkness } \\
\text { of } \mathrm{Yb} \\
\text { layer }(\mathrm{nm})\end{array}$ & $\begin{array}{c}\text { Concentrati } \\
\text { on of } \mathrm{Yb}^{3+} \\
\text { ions }\end{array}$ & $\begin{array}{l}\text { Lifetime } \\
\qquad(\mu \mathrm{s})\end{array}$ \\
\hline \multirow{5}{*}{$\begin{array}{l}\text { Y@xnmYb } \\
@ 99 \% Y b, 1 \\
\text { \%Tm@Y }\end{array}$} & $\tau_{1}-\mathrm{NPs}$ & $0 \mathrm{~nm}$ & $99 \%$ & 867 \\
\hline & $\tau_{2}-\mathrm{NPs}$ & $1.5 \mathrm{~nm}$ & $99 \%$ & 1027 \\
\hline & $\tau_{3}-\mathrm{NPs}$ & $3 \mathrm{~nm}$ & $99 \%$ & 1162 \\
\hline & $\tau_{4}-\mathrm{NPs}$ & $5 \mathrm{~nm}$ & $99 \%$ & 1201 \\
\hline & $\tau_{5}$-NPs & $8 \mathrm{~nm}$ & $99 \%$ & 1282 \\
\hline \multirow{5}{*}{$\begin{array}{l}\mathrm{Y} @ 8 \mathrm{nmYb} \\
@ \mathrm{Y,x} \% \mathrm{Yb}, 1 \\
\text { \%Tm@Y }\end{array}$} & $\tau_{6}$-NPs & $8 \mathrm{~nm}$ & $70 \%$ & 1315 \\
\hline & $\tau_{7}-\mathrm{NPs}$ & $8 \mathrm{~nm}$ & $50 \%$ & 1481 \\
\hline & $\tau_{8}-\mathrm{NPs}$ & $8 \mathrm{~nm}$ & $40 \%$ & 1618 \\
\hline & $\tau_{9}$-NPs & $8 \mathrm{~nm}$ & $20 \%$ & 1721 \\
\hline & $\tau_{10}$-NPs & $8 \mathrm{~nm}$ & $10 \%$ & 2157 \\
\hline
\end{tabular}


Table S2. Compiled upconversion luminescence lifetimes (at $808 \mathrm{~nm}$ ) and structure compostion pertaining to $\mathrm{NaYF}_{4} @ \mathrm{NaYbF}_{4} @ \mathrm{NaYF}_{4}: \mathrm{Yb}^{3+} / \mathrm{Tm}^{3+}$ nanoparticles.

\begin{tabular}{|c|c|c|c|c|}
\hline $\begin{array}{c}\text { Structure } \\
\text { composition }\end{array}$ & $\begin{array}{l}\text { Sample } \\
\text { name }\end{array}$ & $\begin{array}{c}\text { Thinkness } \\
\text { of } \mathrm{Yb} \\
\text { layer }(\mathrm{nm})\end{array}$ & $\begin{array}{c}\text { Concentrati } \\
\text { on of } \mathrm{Yb}^{3+} \\
\text { ions }\end{array}$ & $\begin{array}{l}\text { Lifetime } \\
(\mu \mathrm{s})\end{array}$ \\
\hline \multirow{5}{*}{$\begin{array}{c}\mathrm{Y} @ \mathrm{xnmYb} \\
@ 99 \% \mathrm{Yb}, 1 \\
\% \mathrm{Tm}\end{array}$} & $\tau_{11-\mathrm{NPs}}$ & $0 \mathrm{~nm}$ & $99 \%$ & 126 \\
\hline & $\tau_{12}$-NPs & $1.5 \mathrm{~nm}$ & $99 \%$ & 254 \\
\hline & $\tau_{13}$-NPs & $3 \mathrm{~nm}$ & $99 \%$ & 196 \\
\hline & $\tau_{14-\mathrm{NPs}}$ & $5 \mathrm{~nm}$ & $99 \%$ & 157 \\
\hline & $\tau_{15}$-NPs & $8 \mathrm{~nm}$ & $99 \%$ & 78 \\
\hline \multirow{5}{*}{$\begin{array}{c}\text { Y@8nmYb } \\
@ \text { Y,x\%Yb,1 } \\
\% \mathrm{Tm}\end{array}$} & $\tau_{16}$-NPs & $8 \mathrm{~nm}$ & $70 \%$ & 129 \\
\hline & $\tau_{17-\mathrm{NPs}}$ & $8 \mathrm{~nm}$ & $50 \%$ & 190 \\
\hline & $\tau_{18}$-NPs & $8 \mathrm{~nm}$ & $40 \%$ & 246 \\
\hline & $\tau_{19}$-NPs & $8 \mathrm{~nm}$ & $20 \%$ & 333 \\
\hline & $\tau_{20}$-NPs & $8 \mathrm{~nm}$ & $10 \%$ & 813 \\
\hline
\end{tabular}




\section{References}

1. Tan, M.; Del Rosal, B.; Zhang, Y.; Martin Rodriguez, E.; Hu, J.; Zhou, Z.; Fan, R.; Ortgies, D. H.; Fernandez, N.; Chaves-Coira, I.; Nunez, A.; Jaque, D.; Chen, G., Rare-earth-doped fluoride nanoparticles with engineered long luminescence lifetime for time-gated in vivo optical imaging in the second biological window. Nanoscale 2018, 10 (37), 17771-17780.

2. Fischer, S.; Bronstein, N. D.; Swabeck, J. K.; Chan, E. M.; Alivisatos, A. P., Precise Tuning of Surface Quenching for Luminescence Enhancement in Core-Shell Lanthanide-Doped Nanocrystals. Nano letters 2016, 16 (11), 7241-7247.

3. Li, H.; Xu, L.; Chen, G., Controlled Synthesis of Monodisperse Hexagonal NaYF(4):Yb/Er Nanocrystals with Ultrasmall Size and Enhanced Upconversion Luminescence. Molecules 2017, 22 (12).

4. Zhao, L.; Kutikov, A.; Shen, J.; Duan, C.; Song, J.; Han, G., Stem cell labeling using polyethylenimine conjugated (alpha-NaYbF4:Tm3+)/CaF2 upconversion nanoparticles. Theranostics 2013, 3 (4), 249-57. 